4

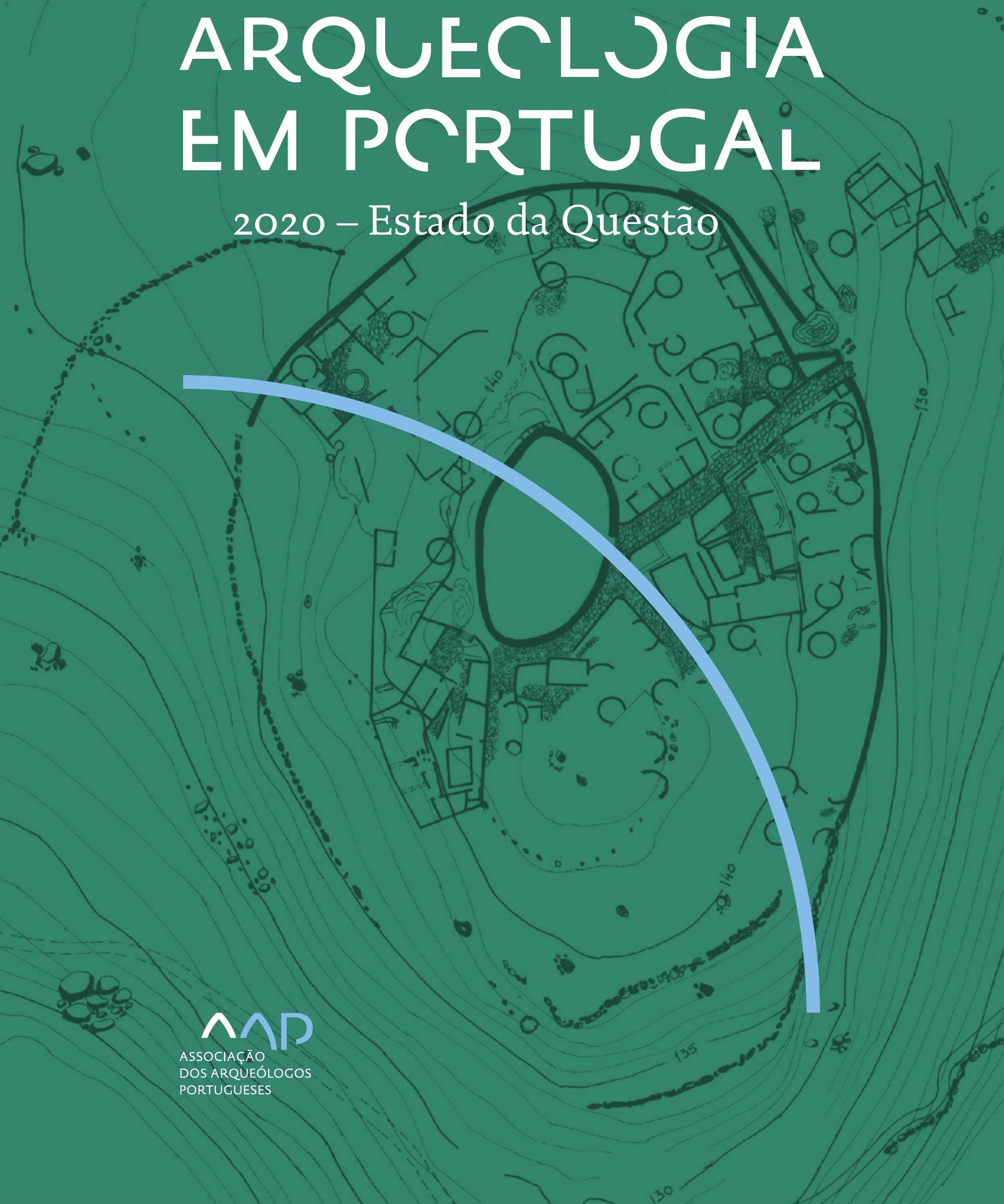


Coordenação editorial: José Morais Arnaud, César Neves e Andrea Martins Design gráfico: Flatland Design

AAP - ISBN: 978-972-9451-89-8

CITCEM - ISBN: 978-989-8970-25-1

Associação dos Arqueólogos Portugueses e CITCEM

Lisboa, 2020

O conteúdo dos artigos é da inteira responsabilidade dos autores. Sendo assim a Associação dos Arqueólogos Portugueses declina qualquer responsabilidade por eventuais equívocos ou questões de ordem ética e legal.

Desenho de capa:

Planta do castro de Monte Mozinho (Museu Municipal de Penafiel).

\section{$\hat{\wedge} \mathrm{P}$}

DOS ARQUEÓLOGOS PORTUGUESES

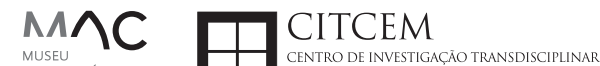
MUSEU
ARQUELLÓGICO
DO CARMO
U.PORTO

FLUP FACULDADE DE LETRAS
UNIVERSIDADE DO PORTO

Apoio

EC para a Ciência 


\section{Índice}

15 Prefácio

José Morais Arnaud

\section{Historiografia e Teoria}

17 Território, comunidade, memória e emoção: a contribuição da história da arqueologia (algumas primeiras e breves reflexões)

Ana Cristina Martins

25 Como descolonizar a arqueologia portuguesa?

Rui Gomes Coelho

41 Arqueologia e Modernidade: uma revisitação pessoal e breve de alguns aspetos da obra homónima de Julian Thomas de 2004

Vítor Oliveira Jorge

57 Dados para a História das Mulheres na Arqueologia portuguesa, dos finais do século XIX aos inícios do século XX: números, nomes e tabelas

Filipa Dimas / Mariana Diniz

73 Retractos da arqueologia portuguesa na imprensa: (in)visibilidades no feminino

Catarina Costeira / Elsa Luís

85 Arqueologia e Arqueólogos no Norte de Portugal Jacinta Bugalhão

101 Vieira Guimarães (1864-1939) e a arqueologia em Tomar: uma abordagem sobre o território e as gentes

João Amendoeira Peixoto / Ana Cristina Martins

115 Os memoráveis? A arqueologia algarvia na imprensa nacional e regional na presente centúria (2001-2019): características, visões do(s) passado(s) e a arqueologia

enquanto marca

Frederico Agosto / João Silva

129 A Evolução da Arqueologia Urbana e a Valorização Patrimonial no Barlavento Algarvio: Os casos de Portimão e Silves

Artur Mateus / Diogo Varandas / Rafael Boavida

\section{Gestão, Valorização e Salvaguarda do Património}

145 O Caderno Reivindicativo e as condições de trabalho em Arqueologia Miguel Rocha / Liliana Matias Carvalho / Regis Barbosa / Mauro Correia / Sara Simões / Jacinta Bugalhão / Sara Brito / Liliana Veríssimo Carvalho / Richard Peace / Pedro Peça / Cézer Santos

155 Os Estudos de Impacte Patrimonial como elemento para uma estratégia sustentável de minimização de impactes no âmbito de reconversões agrícolas Tiago do Pereiro

165 Salvaguarda de Património arqueológico em operações florestais: gestão e sensibilização Filipa Bragança / Gertrudes Zambujo / Sandra Lourenço / Belém Paiva / Carlos Banha / Frederico Tatá Regala / Helena Moura / Jacinta Bugalhão / João Marques / José Correia / Pedro Faria / Samuel Melro

179 Os valores do Património: uma investigação sobre os Sítios Pré-históricos de Arte Rupestre do Vale do Rio Côa e de Siega Verde José Paulo Francisco 
189 Conjugando recursos arqueológicos e naturais para potenciar as visitas ao Geoparque Litoral de Viana do Castelo (Noroeste de Portugal)

Hugo A. Sampaio / Ana M.S. Bettencourt / Susana Marinho / Ricardo Carvalhido

203 Áreas de Potencial Arqueológico na Região do Médio Tejo: Modelo Espacial Preditivo Rita Ferreira Anastácio / Ana Filipa Martins / Luiz Oosterbeek

223 Património Arqueológico e Gestão Territorial: O contributo da Arqueologia para a revisão do PDM de Avis

Ana Cristina Ribeiro

237 A coleção arqueológica do extinto Museu Municipal do Porto - Origens, Percursos e Estudos

Sónia Couto

251 Valpaços - uma nova carta arqueológica

Pedro Pereira / Maria de Fátima Casares Machado

263 Arqueologia na Cidade de Peniche

Adriano Constantino / Luís Rendeiro

273 Arqueologia Urbana: a cidade de Lagos como caso de Estudo Cátia Neto

285 Estratégias de promoção do património cultural subaquático nos Açores. O caso da ilha do Faial

José Luís Neto / José Bettencourt / Luís Borges / Pedro Parreira

297 Carta Arqueológica da Cidade Velha: Uma primeira abordagem

Jaylson Monteiro / Nireide Tavares / Sara da Veiga / Claudino Ramos / Edson Brito /

Carlos Carvalho / Francisco Moreira / Adalberto Tavares

311 Antropologia Virtual: novas metodologias para a análise morfológica e funcional Ricardo Miguel Godinho / Célia Gonçalves

\section{Didáctica da Arqueologia}

327 Como os projetos de Arqueologia podem contribuir para uma comunidade culturalmente mais consciente Alexandra Figueiredo / Claúdio Monteiro / Adolfo Silveira / Ricardo Lopes

337 Educação Patrimonial - Um cidadão esclarecido é um cidadão ativo! Ana Paula Almeida

351 A aproximação da Arqueologia à sala de aula: um caso de estudo no $3^{\circ}$ ciclo do Ensino Básico Luís Serrão Gil

363 Arqueologia 3.o - Pensar e comunicar a Arqueologia para um futuro sustentável Mónica Rolo

377 “Conversa de Arqueólogos" - Divulgar a Arqueologia em tempos de Pandemia Diogo Teixeira Dias

389 Escola Profissional de Arqueologia: desafios e oportunidades Susana Nunes / Dulcineia Pinto / Júlia Silva / Ana Mascarenhas

399 Os Museus de Arqueologia e os Jovens: a oferta educativa para o público adolescente Beatriz Correia Barata / Leonor Medeiros

411 O museu universitário como mediador entre a ciência e a sociedade: o exemplo da secção de arqueologia no Museu de História Natural e da Ciência da Universidade do Porto (MHNC-UP)

Rita Gaspar 
421 Museu de Lanifícios: Real Fábrica de Panos. Atividades no âmbito da Arqueologia Beatriz Correia Barata / Rita Salvado

427 Arqueologia Pública e o caso da localidade da Mata (Torres Novas) Cláudia Manso / Ana Rita Ferreira / Cristiana Ferreira / Vanessa Cardoso Antunes

431 Do sítio arqueológico ao museu: um percurso (também) didático Lídia Fernandes

447 Estão todos convidados para a Festa! E para dançar também... O projecto do Serviço Educativo do Museu Arqueológico do Carmo na $5^{\underline{a}}$ Edição da Festa da Arqueologia Rita Pires dos Santos

459 O “Clã de Carenque”, um projeto didático de arqueologia Eduardo Gonzalez Rocha

469 Mediação cultural: peixe que puxa carroça nas Ruínas Romanas de Troia Inês Vaz Pinto / Ana Patrícia Magalhães / Patrícia Brum / Filipa Santos

481 Didática Arqueológica, experiências do Projeto Mértola Vila Museu Maria de Fátima Palma / Clara Rodrigues / Susana Gómez / Lígia Rafael

\section{Arte Rupestre}

497 Os inventários de arte rupestre em Portugal Mila Simões de Abreu

513 O projeto FIRST-ART - conservação, documentação e gestão das primeiras manifestações de arte rupestre no Sudoeste da Península Ibérica: as grutas do Escoural e Maltravieso Sara Garcês / Hipólito Collado / José Julio García Arranz / Luiz Oosterbeek / António Carlos Silva / Pierluigi Rosina / Hugo Gomes / Anabela Borralheiro Pereira / George Nash / Esmeralda Gomes / Nelson Almeida / Carlos Carpetudo

523 Trabalhos de documentação de arte paleolítica realizados no âmbito do projeto PalæoCôa André Tomás Santos / António Fernando Barbosa / Luís Luís / Marcelo Silvestre / Thierry Aubry

537 Imagens fantasmagóricas, silhuetas elusivas: as figuras humanas na arte do Paleolítico Superior da região do Côa Mário Reis

$55^{1}$ Os motivos zoomórficos representados nas placas de tear de Vila Nova de São Pedro (Azambuja, Portugal) Andrea Martins / César Neves / José M. Arnaud / Mariana Diniz

571 Arte Rupestre do Monte de Góios (Lanhelas, Caminha). Síntese dos resultados dos trabalhos efectuados em 2007-2009 Mário Varela Gomes

599 Gravuras rupestres de barquiformes no Monte de S. Romão, Guimarães, Noroeste de Portugal Daniela Cardoso

613 Círculos segmentados gravados na Bacia do Rio Lima (Noroeste de Portugal): contributos para o seu estudo Diogo Marinho / Ana M.S. Bettencourt / Hugo Aluai Sampaio

631 Equídeos gravados no curso inferior do Rio Mouro, Monção (NW Portugal). Análise preliminar Coutinho, L.M. / Bettencourt, A.M.S / Sampaio, Hugo A.S

645 Paletas na Arte Rupestre do Noroeste de Portugal. Inventário preliminar Bruna Sousa Afonso / Ana M. S. Bettencourt / Hugo A. Sampaio 


\section{Pré-História}

661 O projeto Miño/Minho: balanço de quatro anos de trabalhos arqueológicos Sérgio Monteiro-Rodrigues / João Pedro Cunha-Ribeiro / Eduardo Méndez-Quintas / Carlos Ferreira / Pedro Xavier / José Meireles / Alberto Gomes / Manuel Santonja / Alfredo Pérez-González

677 A ocupação paleolítica da margem esquerda do Baixo Minho: a indústria lítica do sítio de Pedreiras 2 (Monção, Portugal) e a sua integração no contexto regional Carlos Ferreira / João Pedro Cunha-Ribeiro / Sérgio Monteiro-Rodrigues / Eduardo Méndez-Quintas / Pedro Xavier / José Meireles / Alberto Gomes / Manuel Santonja / Alfredo Pérez-González

693 O sítio acheulense do Plistocénico médio da Gruta da Aroeira Joan Daura / Montserrat Sanz / Filipa Rodrigues / Pedro Souto / João Zilhão

703 As sociedades neandertais no Barlavento algarvio: modelos preditivos com recurso aos SIG

Daniela Maio

715 A utilização de quartzo durante o Paleolítico Superior no território dos vales dos rios Vouga e Côa

Cristina Gameiro / Thierry Aubry / Bárbara Costa / Sérgio Gomes / Luís Luís / Carmen Manzano / André Tomás Santos

733 Uma perspetiva diacrónica da ocupação do concheiro do Cabeço da Amoreira (Muge, Portugal) a partir da tecnologia lítica Joana Belmiro / João Cascalheira / Célia Gonçalves

745 Novos dados sobre a Pré-história Antiga no concelho de Palmela. A intervenção arqueológica no sítio do Poceirão I

Michelle Teixeira Santos

757 Problemas em torno de Datas Absolutas Pré-Históricas no Norte do Alentejo Jorge de Oliveira

771 Povoamento pré-histórico nas áreas montanhosas do NO de Portugal: o Abrigo 1 de Vale de Cerdeira Pedro Xavier / José Meireles / Carlos Alves

783 Apreciação do povoamento do Neolítico Inicial na Baixa Bacia do Douro. A Lavra I (Serra da Aboboreira) como caso de estudo Maria de Jesus Sanches

797 O Processo de Neolitização na Plataforma do Mondego: os dados do Sector C do Outeiro dos Castelos de Beijós (Carregal do Sal)

João Carlos de Senna-Martinez / José Manuel Quintã Ventura / Andreia Carvalho / Cíntia Maurício

823 Novos trabalhos na Lapa da Bugalheira (Almonda, Torres Novas) Filipa Rodrigues / Pedro Souto / Artur Ferreira / Alexandre Varanda / Luís Gomes / Helena Gomes / João Zilhão

837 A pedra polida e afeiçoada do sítio do Neolítico médio da Moita do Ourives (Benavente, Portugal)

César Neves

857 Casal do Outeiro (Encarnação, Mafra): novos contributos para o conhecimento do povoamento do Neolítico final na Península de Lisboa.

Cátia Delicado / Carlos Maneira e Costa / Marta Miranda / Ana Catarina Sousa

873 Stresse infantil, morbilidade e mortalidade no sítio arqueológico do Neolítico Final/ Calcolítico ( $4^{\circ}$ e $3^{\circ}$ milénio a.C.) do Monte do Carrascal 2 (Ferreira do Alentejo, Beja) Liliana Matias de Carvalho / Sofia N. Wasterlain 
885 Come together: O Conjunto Megalítico das Motas (Monção, Viana do Castelo) e as expressões Campaniformes do Alto Minho Ana Catarina Basílio / Rui Ramos

899 Trabalhos arqueológicos no sítio Calcolítico da Pedreira do Poio Carla Magalhães / João Muralha / Mário Reis / António Batarda Fernandes

913 O sítio arqueológico de Castanheiro do Vento. Da arquitectura do sítio à arquitectura de um território João Muralha Cardoso

925 Estudo zooarqueológico das faunas do Calcolítico final de Vila Nova de São Pedro (Azambuja, Portugal): Campanhas de 2017 e 2018 Cleia Detry / Ana Catarina Francisco / Mariana Diniz / Andrea Martins / César Neves / José Morais Arnaud

943 As faunas depositadas no Museu Arqueológico do Carmo provenientes de Vila Nova de São Pedro (Azambuja): as campanhas de 1937 a 1967 Ana Catarina Francisco / Cleia Detry / César Neves / Andrea Martins / Mariana Diniz / José Morais Arnaud

959 Análise funcional de material lítico em sílex do castro de Vila Nova de S. Pedro (Azambuja, Portugal): uma primeira abordagem Rafael Lima

971 O recinto da Folha do Ouro 1 (Serpa) no contexto dos recintos de fossos calcolíticos alentejanos

António Carlos Valera / Tiago do Pereiro / Pedro Valério / António M. Monge Soares

\section{Proto-História}

987 Produção de sal marinho na Idade do Bronze do noroeste Português. Alguns dados para uma reflexão

Ana M. S. Bettencourt / Sara Luz / Nuno Oliveira / Pedro P. Simões / Maria Isabel C. Alves / Emílio Abad-Vidal

1001 A estátua-menir do Pedrão ou de São Bartolomeu do Mar (Esposende, noroeste de Portugal) no contexto arqueológico da fachada costeira de entre os rios Neiva e Cávado Ana M. S. Bettencourt / Manuel Santos-Estévez / Pedro Pimenta Simões / Luís Gonçalves

1015 O Castro do Muro (Vandoma/Baltar, Paredes) - notas para uma biografia de ocupação da Idade do Bronze à Idade Média

Maria Antónia D. Silva / Ana M. S. Bettencourt / António Manuel S. P. Silva / Natália Félix

1031 Do Bronze Final à Idade Média - continuidades e hiatos na ocupação de Povoados em Oliveira de Azeméis João Tiago Tavares / Adriaan de Man

1041 As faunas do final da Idade do Bronze no Sul de Portugal: leituras desde o Outeiro do Circo (Beja)

Nelson J. Almeida / Íris Dias / Cleia Detry / Eduardo Porfírio / Miguel Serra

1055 A Espada do Monte das Oliveiras (Serpa) - uma arma do Bronze Pleno do Sudoeste Rui M. G. Monge Soares / Pedro Valério / Mariana Nabais / António M. Monge Soares

1065 São Julião da Branca (Albergaria-a-Velha) - Investigação e valorização de um povoado do Bronze Final

António Manuel S. P. Silva / Paulo A. P. Lemos / Sara Almeida e Silva / Edite Martins de Sá

1083 Do castro de S. João ao Mosteiro de Santa Clara: notícia de uma intervenção arqueológica, em Vila do Conde Rui Pinheiro 
1095 O castro de Ovil (Espinho), um quarto de século de investigação - resultados e questões em aberto

Jorge Fernando Salvador / António Manuel S. P. Silva

1111 O Castro de Salreu (Estarreja), um povoado proto-histórico no litoral do Entre Douro e Vouga

Sara Almeida e Silva / António Manuel S. P. Silva / Paulo A. P. Lemos / Edite Martins de Sá

1127 Castro de Nossa Senhora das Necessidades (Sernancelhe): uma primeira análise artefactual Telma Susana O. Ribeiro

${ }_{1141}$ A cividade de Bagunte. O estado atual da investigação Pedro Brochado de Almeida

1153 Zoomorfos na cerâmica da Idade do Ferro no NW Peninsular: inventário, cronologias e significado Nuno Oliveira / Cristina Seoane

1163 Vasos gregos em Portugal: diferentes maneiras de contar a história do intercâmbio cultural na Idade do Ferro

Daniela Ferreira

1175 Os exotica da necrópole da Idade do Ferro do Olival do Senhor dos Mártires (Alcácer do Sal) no seu contexto regional

Francisco B. Gomes

\section{Antiguidade Clássica e Tardia}

1191 O uso de madeira como combustível no sítio da Quinta de Crestelos (Baixo Sabor): da Idade do Ferro à Romanização Filipe Vaz / João Tereso / Sérgio Simões Pereira / José Sastre / Javier Larrazabal Galarza / Susana Cosme / José António Pereira / Israel Espi

1207 Cultivos de Época Romana no Baixo Sabor: continuidade em tempos de mudança? João Pedro Tereso / Sérgio Simões Pereira / Filipe Santos / Luís Seabra / Filipe Vaz

1221 A casa romana na Hispânia: aplicação dos modelos itálicos nas províncias ibéricas Fernanda Magalhães / Diego Machado / Manuela Martins

1235 As pinturas murais romanas da Rua General Sousa Machado, n. ${ }^{5}$ 1, Chaves José Carvalho

1243 Trás do Castelo (Vale de Mir, Pegarinhos, Alijó) - Uma exploração agrícola romana do Douro

Tony Silvino / Pedro Pereira

1255 A sequência de ocupação no quadrante sudeste de Bracara Augusta: as transformações de uma unidade doméstica Lara Fernandes / Manuela Martins

1263 Os Mosaicos com decoração geométrica e geométrico-vegetalista dos sítios arqueológicos da área do Conuentus Bracaraugustanus. Novas abordagens quanto à conservação, restauro, decoração e datação Maria de Fátima Abraços / Licínia Wrench

1277 “Casa Romana” do Castro de São Domingos (Cristelos, Lousada): Escavação, Estudo e Musealização Paulo André de P. Lemos

1291 A arqueobotânica no Castro de Guifões (Matosinhos, Noroeste de Portugal): O primeiro estudo carpológico

Luís Seabra / Andreia Arezes / Catarina Magalhães / José Varela / João Pedro Tereso 
1305 Um Horreum Augustano na Foz do Douro (Monte do Castelo de Gaia, Vila Nova de Gaia) Rui Ramos

1311 Ponderais romanos na Lusitânia: padrões, formas, materiais e contextos de utilização Diego Barrios Rodríguez

1323 Um almofariz centro-itálico na foz do Mondego

Marco Penajoia

1335 Estruturas romanas de Carnide - Lisboa Luísa Batalha / Mário Monteiro / Guilherme Cardoso

1347 O contexto funerário do sector da "necrópole NO" da Rua das Portas de S. Antão (Lisboa): o espaço, os artefactos, os indivíduos e a sua interconectividade na interpretação do passado Sílvia Loja, José Carlos Quaresma, Nelson Cabaço, Marina Lourenço, Sílvia Casimiro, Rodrigo Banha da Silva, Francisca Alves-Cardoso

${ }_{1361}$ Povoamento em época Romana na Amadora - resultados de um projeto pluridisciplinar Gisela Encarnação / Vanessa Dias

1371 A Arquitectura Residencial em Mirobriga (Santiago do Cacém): contributo a partir de um estudo de caso Filipe Sousa / Catarina Felício

${ }_{1385}$ O fim do ciclo. Saneamento e gestão de resíduos nos edifícios termais de Mirobriga (Santiago do Cacém)

Catarina Felício / Filipe Sousa

1399 Balsa, Topografia e Urbanismo de uma Cidade Portuária Vítor Silva Dias / João Pedro Bernardes / Celso Candeias / Cristina Tété Garcia

1413 No Largo das Mouras Velhas em Faro (2017): novas evidências da necrópole norte de Ossonoba e da sua ocupação medieval Ricardo Costeira da Silva / Paulo Botelho / Fernando Santos / Liliana Nunes

1429 Instrumentos de pesca recuperados numa fábrica de salga em Ossonoba (Faro) Inês Rasteiro / Ricardo Costeira da Silva / Paulo Botelho

1439 A Necrópole Romana do Eirô, Duas Igrejas (Penafiel): intervenção arqueológica de 2016 Laura Sousa / Teresa Soeiro

1457 Ritual, descarte ou afetividade? A presença de Canis lupus familiaris na Necrópole Noroeste de Olisipo (Lisboa)

Beatriz Calapez Santos / Sofia Simões Pereira / Rodrigo Banha da Silva / Sílvia Casimiro / Cleia Detry / Francisca Alves Cardoso

1467 Dinâmicas económicas em Bracara na Antiguidade Tardia Diego Machado / Manuela Martins / Fernanda Magalhães / Natália Botica

1479 Cerâmicas e Vidros da Antiguidade Tardia do Edifício sob a Igreja do Bom Jesus (Vila Nova de Gaia) Joaquim Filipe Ramos

1493 Novos contributos para a topografia histórica de Mértola no período romano e na Antiguidade Tardia Virgílio Lopes

\section{8. Época Medieval}

1511 Cerâmicas islâmicas no Garb setentrional "português": algumas evidências e incógnitas Constança dos Santos / Helena Catarino / Susana Gómez / Maria José Gonçalves / Isabel Inácio / Gonçalo Lopes / Jacinta Bugalhão / Sandra Cavaco / Jaquelina Covaneiro / Isabel Cristina Fernandes / Ana Sofia Gomes 
1525 Contributo para o conhecimento da cosmética islâmica, em Silves, durante a Idade Média Rosa Varela Gomes

1537 Yábura e o seu território - uma análise histórico-arqueológica de Évora entre os séculos VIII-XII José Rui Santos

1547 A encosta sul do Castelo de Palmela - resultados preliminares da escavação arqueológica Luís Filipe Pereira / Michelle Teixeira Santos

1559 A igreja de São Lourenço (Mouraria, Lisboa): um conjunto de silos e de cerâmica medieval islâmica

Andreia Filipa Moreira Rodrigues

1571 O registo material de movimentações populacionais no Médio Tejo, durante os séculos XII-XIII. Dois casos de "sunken featured buildings", nos concelhos de Cartaxo e Torres Novas Marco Liberato / Helena Santos / Nuno Santos

1585 O nordeste transmontano nos alvores da Idade média. Notas para reflexão Ana Maria da Costa Oliveira

1601 Sepulturas escavadas na rocha do Norte de Portugal e do Vale do Douro: primeiros resultados do Projecto SER-NPVD

Mário Jorge Barroca / César Guedes / Andreia Arezes / Ana Maria Oliveira

1619 "Portucalem Castrum Novum" entre o Mediterrâneo e o Atlântico: o estudo dos materiais cerâmicos alto-medievais do arqueossítio da rua de D. Hugo, nํ. 5 (Porto) João Luís Veloso

1627 A Alta Idade Média na fronteira de Lafões: notas preliminares sobre a Arqueologia no Concelho de Vouzela

Manuel Luís Real / Catarina Tente

1641 Um conjunto cerâmico medieval fora de portas: um breve testemunho aveirense Susana Temudo

${ }_{1651}$ Os Lóios do Porto: uma perspetiva integrada no panorama funerário da Baixa Idade Média à Época Moderna em meios urbanos em Portugal

Ana Lema Seabra

1659 O Caminho Português Interior de Santiago como eixo viário na Idade Média Pedro Azevedo

1665 Morfologia Urbana: Um exercício em torno do Castelo de Ourém André Donas-Botto / Jaqueline Pereira

1677 Intervenção arqueológica na Rua Marquês de Pombal/Largo do Espírito Santo (Bucelas, Loures)

Florbela Estêvão / Nathalie Antunes-Ferreira / Dário Ramos Neves / Inês Lisboa

1691 O Cemitério Medieval do Poço do Borratém e a espacialidade funerária na cidade de Lisboa Inês Belém / Vanessa Filipe / Vasco Noronha Vieira / Sónia Ferro / Rodrigo Banha da Silva

1705 Um Espaço Funerário Conventual do séc. XV em Lisboa: o caso do Convento de São Domingos da Cidade Sérgio Pedroso / Sílvia Casimiro / Rodrigo Banha da Silva / Francisca Alves Cardoso

\section{9. Época Moderna e Contemporânea}

1721 Arqueologia Moderna em Portugal: algumas reflexões críticas em torno da quantificação de conjuntos cerâmicos e suas inferências históricas e antropológicas Rodrigo Banha da Silva / André Bargão / Sara da Cruz Ferreira

1733 Faianças de dois contextos entre os finais do século XVI e XVIII do Palácio dos Condes de Penafiel, Lisboa

Martim Lopes / Tomás Mesquita 
1747 Um perfil de consumo do século XVIII na foz do Tejo: O caso do Mercado da Ribeira, Lisboa Sara da Cruz Ferreira / Rodrigo Banha da Silva / André Bargão

1761 Os Cachimbos dos Séculos XVII e XVIII do Palácio Mesquitela e Convento dos Inglesinhos (Lisboa)

Inês Simão / Marina Pinto / João Pimenta / Sara da Cruz Ferreira / André Bargão / Rodrigo Banha da Silva

1775 "Tomar os fumos da erua que chamão em Portugal erua sancta». Estudo de Cachimbos provenientes da Rua do Terreiro do Trigo, Lisboa

Miguel Martins de Sousa / José Pedro Henriques / Vanessa Galiza Filipe

1787 Cachimbos de Barro Caulínitico da Sé da Cidade Velha (República de Cabo Verde)

Rodrigo Banha da Silva / João Pimenta / Clementino Amaro

1801 Algumas considerações sobre espólio não cerâmico recuperado no Largo de Jesus (Lisboa) Carlos Boavida

1815 Adereços de vidro, dos séculos XVI-XVIII, procedentes do antigo Convento de Santana de Lisboa (anéis, braceletes e contas)

Joana Gonçalves / Rosa Varela Gomes / Mário Varela Gomes

1837 Da ostentação, luxo e poder à simplicidade do uso quotidiano: arqueologia e simbologia de joias e adornos da Idade Moderna Portuguesa Jéssica Iglésias

1849 Os amuletos em Portugal - dos objetos às superstições: o coral vermelho Alexandra Vieira

1865 Cerâmicas de Vila Franca de Xira nos séculos XV e XVI Eva Pires

1879 «Não passa por teu o que me pertence». Marcas de individualização associadas a faianças do Convento de Nossa Senhora de Aracoeli, Alcácer do Sal Catarina Parreira / Íris Fragoso / Miguel Martins de Sousa

1891 Cerâmica de Leiria: alguns focos de produção

Jaqueline Pereira / André Donas-Botto

1901 Os Fornos na Rua da Biquinha, em Óbidos Hugo Silva / Filipe Oliveira

1909 A casa de Pêro Fernandes, contador dos contos de D. Manuel I: o sítio arqueológico da Silha do Alferes, Seixal (século XVI) Mariana Nunes Ferreira

1921 O Alto da Vigia (Sintra) e a vigilância e defesa da costa Alexandre Gonçalves / Sandra Santos

1937 O contexto da torre sineira da Igreja de Santa Maria de Loures Paulo Calaveira / Martim Lopes

1949 A Necrópole do Hospital Militar do Castelo de São Jorge e as práticas funerárias na Lisboa de Época Moderna Susana Henriques / Liliana Matias de Carvalho / Ana Amarante / Sofia N. Wasterlain

1963 SAND - Sarilhos Grandes Entre dois Mundos: o adro da Igreja e a Paleobiologia dos ossos humanos recuperados

Paula Alves Pereira / Roger Lee Jesus / Bruno M. Magalhães

1975 Expansão urbana da vila de Cascais no século XVII e XVIII: a intervenção arqueológica na Rua da Vitória no 15 a 17

Tiago Pereira / Vanessa Filipe

1987 Novos dados para o conhecimento do Urbanismo de Faro em época Moderna Ana Rosa 
1995 Um exemplo de Arqueologia Urbana em Alcoutim: o Antigo Edifício dos CTT Marco Fernandes / Marta Dias / Alexandra Gradim / Virgílio Lopes / Susana Gómez Martínez

2007 Palácio dos Ferrazes (Rua das Flores/Rua da Vitória, Porto): a cocheira de Domingos Oliveira Maia

Francisco Raimundo

2021 As muitas vidas de um edifício urbano: História, Arqueologia e Antropologia no antigo Recreatório Paroquial de Penafiel Helena Bernardo / Jorge Sampaio / Marta Borges

2035 O convento de Nossa Senhora da Esperança de Ponta Delgada: o contributo da arqueologia para o conhecimento de um monumento identitário João Gonçalves Araújo / N’Zinga Oliveira

2047 Arqueologia na ilha do Corvo... em busca da capela de Nossa Senhora do Rosário Tânia Manuel Casimiro / José Luís Neto / Luís Borges / Pedro Parreira

2059 Perdidos à vista da Costa. Trabalhos arqueológicos subaquáticos na Barra do Tejo Jorge Freire / José Bettencourt / Augusto Salgado

2071 Arqueologia marítima em Cabo Verde: enquadramento e primeiros resultados do projecto CONCHA

José Bettencourt / Adilson Dias / Carlos Lima / Christelle Chouzenoux / Cristóvão Fonseca / Dúnia Pereira / Gonçalo Lopes / Inês Coelho / Jaylson Monteiro / José Lima / Maria Eugénia Alves / Patrícia Carvalho / Tiago Silva

2085 Trabalhos arqueológicos na Cidade Velha (Ribeira Grande de Santiago, Cabo Verde): reflexões sobre um projecto de investigação e divulgação patrimonial André Teixeira / Jaylson Monteiro / Mariana Mateus / Nireide Tavares / Cristovão Fonseca / Gonçalo C. Lopes / Joana Bento Torres / Dúnia Pereira / André Bargão / Aurélie Mayer / Bruno Zélie / Carlos Lima / Christelle Chouzenoux / Inês Henriques / Inês Pinto Coelho / José Lima / Patrícia Carvalho / Tiago Silva

2103 A antiga fortificação de Quelba / Khor Kalba (E.A.U.). Resultados de quatro campanhas de escavações, problemáticas e perspectivas futuras Rui Carita / Rosa Varela Gomes / Mário Varela Gomes / Kamyar Kamyad

2123 Colónias para homens novos: arqueologia da colonização agrária fascista no noroeste ibérico Xurxo Ayán Vila / José Mạ . Señorán Martín 


\title{
O PROJETO MIÑO/MINHO: BALANÇO DE QUATRO ANOS DE TRABALHOS ARQUEOLÓGICOS
}

Sérgio Monteiro-Rodrigues ${ }^{1}$, João Pedro Cunha-Ribeiro² ${ }^{2}$ Eduardo Méndez-Quintas ${ }^{3}$, Carlos Ferreira ${ }^{4}$, Pedro Xavier ${ }^{5}$, José Meireles ${ }^{6}$, Alberto Gomes ${ }^{7}$, Manuel Santonja $^{8}$, Alfredo Pérez-González ${ }^{9}$

RESUMO

Apresentam-se os resultados mais significativos do projeto Miño/Minho, após quatro anos de trabalhos de campo (2016-2019). Os principais sítios intervencionados - Pedreiras 2 e Bela, Monção, e Carvalhas (loci 1, 2, 3 e 4), Melgaço -, associados a depósitos fluviais do rio Minho ou a formações deles derivadas, forneceram indústrias líticas talhadas, genericamente enquadráveis no tecno-complexo Acheulense. Tendo em conta outros dados obtidos na região, mais especificamente na margem direita do rio Minho (Galiza), estas indústrias datarão de diferentes momentos dentro do Pleistocénico médio.

Palavras-chave: Acheulense, Rio Minho, Monção, Melgaço.

\begin{abstract}
The most significant results of the Miño-Minho project after four years of fieldwork (2016-2019) are presented. The main sites - Pedreiras 2 and Bela, Monção, and Carvalhas (loci 1, 2, 3 and 4), Melgaço -, associated with fluvial deposits of the Minho River or with formations derived from them, provided lithic assemblages that can be connected with the Acheulean techno-complex. Taking into account data obtained in the region, more specifically on the right bank of the Minho River (Galicia), these assemblages may date from different moments within the Middle Pleistocene.
\end{abstract}

Keywords: Acheulean, Minho River, Monção, Melgaço.

\section{INTRODUÇÃO}

Os trabalhos de investigação sobre os terraços do rio Minho e sobre as indústrias líticas a eles associadas remontam aos finais do século XIX, desenvolvendo-se ao longo do século XX tanto no território portu- guês como na Galiza, embora a ritmos bastante diferenciados (Cunha-Ribeiro $\&$ alii, 2017).

No novo milénio, as investigações na região prosseguiram, sendo de destacar dois projetos independentes entre si, com objetivos e áreas de intervenção distintos. O primeiro projeto - no quadro de uma

\footnotetext{
1. Faculdade de Letras, Universidade do Porto; Centro de Investigação Transdisciplinar “Cultura, Espaço e Memória” (CITCEM); sergiomonteirorodrigues@gmail.com

2. Faculdade de Letras, Universidade de Lisboa; Centro de Arqueologia da Universidade de Lisboa (UNIARQ); Lab2pt; jpcunharibeiro@letras.ulisboa.pt

3. Grupo de Estudos de Arqueoloxía, Antigüidade e Territorio (GEAAT), University of Vigo, Campus As Lagoas, 32004 Ourense, Spain; eduardo.mendez.quintas@uvigo.es

4. Faculdade de Letras, Universidade de Lisboa; carlos.felipe11@gmail.com

5. UMinho; Lab2pt; pedroxavy@gmail.com

6. UMinho; Lab2pt; jmeireles@uaum.uminho.pt

7. Faculdade de Letras, Universidade do Porto; Centro de Estudos de Geografia e Ordenamento do Territorio (CEGOT); albgomes@gmail.com

8. Centro Nacional de Investigacion sobre la Evolucion Humana (CENIEH), Burgos; manuel.santonja@cenieh.es.

9. IDEA, Instituto de Evolución en África, Covarrubias 36, 28010 Madrid; alfredopg41@hotmail.com
} 
tese de doutoramento defendida em 2013 na Universidade de Wageningen, Holanda - centrou-se na análise do controlo exercido pela tectónica na evolução do sistema de terraços fluviais, de origem glacio-eustática, do Baixo Minho (Viveen, 2013; Viveen \& alii, 2013a, 2013b, 2014). Realizado em ambas as margens do rio, este estudo permitiu identificar 10 níveis de terraço, dispostos em escadaria a partir da atual planície aluvial, tendo as respetivas interpretações conduzido à realização de um registo cartográfico das várias formações sedimentares (Viveen \& alii, 2013a). A combinação de datações obtidas por OSL e por isótopos cosmogénicos $\left({ }^{\circ} \mathrm{Be}\right)$ em depósitos da margem esquerda do rio Minho, a jusante de Valença (Viveen $\&$ alii, 2012), confirmaram o alargado período de tempo em que terá decorrido a formação dos terraços fluviais, considerando-se os mais elevados anteriores à transição do Pleistocénico Inferior para o Pleistocénico Médio (>780 Ka), e distribuindo-se os restantes entre o início do Pleistocénico Médio e o Pleistocénico Superior.

A par do trabalho de W. Viveen, exclusivamente de âmbito geomorfológico, desenvolveu-se, na margem direita do Minho, um outro programa de investigação centrado no estudo geoarqueológico das ocupações paleolíticas aí existentes (Méndez-Quintas, 2017; Méndez-Quintas \& alii, 2019a; Méndez-Quintas \& alii, 2020a). Com ele pretendeu-se (e pretende-se ainda) dar continuidade aos projetos pontuais iniciados nos anos oitenta e nos finais da década de noventa (Cunha-Ribeiro $\&$ alii, 2017), seguindo-se agora uma perspetiva mais atualizada e com forte cariz interdisciplinar, fruto de avanços técnicos e metodológicos, que procurou também integrar a realidade arqueológica regional no âmbito mais alargado da Península Ibérica (Méndez-Quintas \& alii, 2019a, 2O2Oa; 2O2Ob; Demuro \& alii, 2020).

A existência ou não de uma ocupação anterior ao Pleistocénico Médio e a caracterização das indústrias acheulenses localmente representadas, tanto no que diz respeito à sua "origem" como ao seu devir, foram algumas das problemáticas que E. Méndez-Quintas almejou esclarecer. Para o efeito privilegiou o estudo de sítios e de materiais líticos que se encontravam associados a contextos estratigráficos bem definidos, promovendo concomitantemente o estudo desses mesmos contextos, em geral correspondentes a terraços fluviais ou a depósitos deles derivados. Neste sentido, não só se recuperaram os trabalhos anteriormente realizados na jazida de As Gándaras de
Budiño (Aguirre, 1964; Butzer, 1967; Vidal Encinas, 1982a, 1982b; Texier, 1984; Texier \& alii, 1981; Giles Pacheco \& alii, 2000; Méndez-Quintas, 2007, 2008; Méndez-Quintas $\mathbb{Z}$ alii, 2019b), como também se procedeu ao estudo de novas jazidas, que determinaram a realização de sondagens e de escavações, nalguns casos com resultados excecionais. Foi o caso de O Cabrón, no concelho de Arbo, onde foi possível reconhecer materiais líticos talhados associáveis ao tecno-complexo Acheulense, com uma datação mínima de 119.000 anos (Méndez-Quintas $\&$ alii, 2018c). Na jazida de Porto Maior, no concelho de As Neves, identificaram-se quatro distintos níveis de ocupação acheulense, datados de 300.0000 a 200.000 anos, destacando-se a descoberta num desses níveis, em posição primária, de uma inusitada concentração de bifaces, machados de mão e triedros, com morfologias e dimensões que encontram paralelo apenas em contextos africanos (Méndez-Quintas \& alii, 2018) (Figura 1).

Os projetos de W. Viveen e de E. Méndez-Quintas foram por nós assumidos como o ponto de partida para a realização do nosso próprio projeto, que denominámos Miño/Minho. De momento, os trabalhos daqueles investigadores reúnem a informação mais atualizada sobre os terraços fluviais do Baixo Minho e sobre as indústrias líticas acheulenses a eles associadas.

\section{O PROJETO DE INVESTIGAÇÃO MIÑO/MINHO}

O projecto Miño/Minho - Os primeiros habitantes do Baixo Minho. Estudo das ocupações pleistocénicas da região, submetido em 2015 à Direção Geral do Património Cultural como Projeto de Investigação Plurianual de Arqueologia (PIPA), teve como principal objetivo, como se referiu, dar continuidade aos trabalhos levados a cabo nos últimos anos na Galiza, no setor do Baixo Minho (Cunha-Ribeiro \& alii, 2017), conduzidos por Eduardo Méndez-Quintas, Manuel Santonja Gómez e Alfredo Pérez González (Méndez-Quintas, 2017; Méndez-Quintas \& alii, 2018, 2019a, 2019c; Méndez-Quintas \& alii, 2020a). O projecto Miño/Minho pretende, assim, estudar os mais antigos vestígios da presença humana na área do curso final do rio Minho, entre a confluência com o rio Trancoso, na sua margem esquerda, e a foz, 75 $\mathrm{km}$ a jusante. Os referidos vestígios, correspondendo a indústrias líticas de idade paleolítica, surgem 
conservados em formações sedimentares pleistocénicas, nomeadamente em terraços fluviais, que se desenvolvem ao longo de ambas as margens do rio (Cunha Ribeiro \& alii, 2017) (Figura 2).

Os diversos trabalhos arqueológicos realizados entre 2016 e 2019 - que incluíram prospeções e escavações - permitem uma primeira caraterização do Paleolítico Inferior do Baixo Minho, nomeadamente da margem portuguesa, até há pouco tempo conhecido apenas através de pequenos conjuntos artefactuais provenientes de contextos algo imprecisos (Cunha-Ribeiro \& alii, 2017, 2018; Méndez-Quintas $\&$ alii, 2020b).

\subsection{Concelho de Monção: os sítios de Pedreiras 1, Pedreiras 2 e Bela}

\section{Pedreiras 1 e Pedreiras 2}

Em 2016 e 2017, os trabalhos arqueológicos efetuados em Monção concentraram-se na área da União de Freguesias de Messegães, Valadares e Sá, mais precisamente junto à povoação de Bemposta, incidindo nas jazidas de Pedreiras 1 e Pedreiras 2.

A importância arqueológica de Pedreiras 1 foi assinalada por um arqueólogo amador de nacionalidade espanhola, Manuel Ledo, que relatou ter ali identificado diversos artefactos líticos talhados, aquando da abertura da variante à EN 202, que liga Monção a Melgaço. Segundo M. Ledo, parte dos artefactos líticos surgiram no talude que ladeia a norte a referida variante.

Em função desta informação - mais tarde sustentada pela descoberta de um biface e de um núcleo na área em questão por um dos membros do projeto Minho/Miño (J. P. Cunha Ribeiro) - procedeu-se, em 2016, à abertura de uma sondagem de $2 \mathrm{~m}^{2}$ na parte superior do talude com o objectivo de aferir a real importância arqueológica do local. No entanto, a sondagem viria a ser rapidamente abandonada porque depois da remoção do delgado solo vegetal logo se atingiu o substrato granítico. Os trabalhos voltaram-se, então, para a limpeza e regularização de um pequeno corte que ladeia um caminho, um pouco mais para poente, onde era visível um depósito com seixos rolados de quartzito e quartzo. Estas acções permitiram constatar que se estava perante uma formação coluvionar, com pouca possança (Figura 3), muito pobre do ponto de vista arqueológico. De facto, nas Pedreiras 1 não foi recolhido qualquer artefacto suscetível de diagnosticar a co- leção exumada, tanto em termos tecno-tipológicos, como em termos cronológico-culturais.

Terminada a intervenção inicial, e ainda em 2016, optou-se por dirigir a atenção para um outro ponto mais a oeste - que foi denominado Pedreiras 2 onde um derrube do talude de um caminho de terra batida havia exposto alguns artefactos líticos associáveis ao tecno-complexo Acheulense, nomeadamente um biface de grandes dimensões, sobre seixo rolado de quartzito (Figura 4). A sua descoberta ocorreu quando um dos autores (Alberto Gomes) procedia a um dos vários reconhecimentos geomorfológicos da área em torno das jazidas de Pedreiras. No sentido de compreender o contexto estratigráfico dos referidos artefactos procedeu-se não só à limpeza da vegetação na totalidade do talude, como também à sua verticalização e posterior registo detalhado. Estes trabalhos permitiram a recolha de mais material lítico, que, entretanto, se verificou estar associado exclusivamente a depósitos coluvionares canalizados, que se embutiam em sedimentos arenosos finos de origem fluvial (possivelmente de inundação) (Figura 4). Tal situação aconselhou a abertura de uma sondagem na parte superior do talude (sondagem 1), visando-se dois objetivos: verificar o desenvolvimento em profundidade dos depósitos coluvionares e avaliar a sua real extensão, nomeadamente para o lado sul da jazida.

Relativamente ao primeiro objetivo, a sondagem revelou a existência, a cerca de $2 \mathrm{~m}$ de profundidade, de uma camada cascalhenta-matriz-suportada, composta por areias grosseiras, seixos rolados de quartzito e de quartzo e blocos de granito - à qual se associava a indústria lítica das Pedreiras 2 (Figura 4). Embora em posição secundária, o estado físico dos artefactos líticos, essencialmente com arestas vivas, sugere um transporte de curta distância, possivelmente de uma zona próxima de cota ligeiramente mais alta, em fluxos de muito baixa energia. Os trabalhos realizados em 2017 - que consistiram, essencialmente, na abertura de mais sondagens na parte superior do talude (Figura 4) - mostraram que os artefactos tendiam a concentrar-se numa área relativamente restrita, o que corrobora a hipótese de se estar perante uma coleção homogénea.

Relativamente ao segundo objetivo, as intervenções de 2017 permitiram constatar que as coluviões se circunscreviam às imediações do talude, não se conhecendo ainda com rigor nem o desenvolvimento nem a orientação dos canais que estas originam (Figura 4). 
No que concerne especificamente aos materiais exumados (200 peças), em excelente estado físico, os resultados obtidos permitem registar a presença de uma indústria enquadrável no tecno-complexo Acheulense, associada ao predomínio de cadeias operatórias de debitagem relativamente expeditas e simples. Com efeito, paralelamente à presença de produtos configurados característicos deste tecno-complexo (bifaces e machados de mão), provavelmente introduzidos no local já em fase de uso, documenta-se a existência de um conjunto principal constituído por produtos de debitagem relativamente expeditos, elaborados maioritariamente a partir da exploração de seixos rolados de quartzito (Ferreira \& alii, neste volume).

Em suma, o valor da indústria lítica de Pedreiras 2, em sintonia com a realidade documentada nas jazidas do Baixo Minho, com uma cadeia operatória com uma composição análoga à documentada nas jazidas da margem direita, e ainda noutros conjuntos acheulenses peninsulares (Ferreira \& alii, neste volume), expressa-se pelo facto de se estar perante a primeira estação arqueológica Acheulense na área do Concelho de Monção, onde até há poucos anos se conheciam apenas artefactos líticos isolados.

\section{Bela}

Com o objectivo de aprofundar os conhecimentos sobre a evolução geomorfológica do setor do rio Minho compreendido entre Monção e Melgaço, realizou-se, em abril de 2018, uma saída de campo que visou essencialmente o reconhecimento de alguns terraços fluviais assinalados na cartografia geológica. Durante os trabalhos levados a cabo na freguesia de Bela, a cerca de $5 \mathrm{Km}$ a leste de Monção, detetaram-se algumas peças talhadas num talude subjacente à EN 202. Após a sua limpeza sumária, verificou-se que o material arqueológico era abundante, pelo que se decidiu proceder à realização de sondagens de diagnóstico na área, o que veio a acontecer em maio de 2019 (Figura 5).

Apesar de duas das sondagens se revelarem estéreis do ponto de vista arqueológico (mas ainda assim com dados importantes para o entendimento da morfogénese do sítio), noutras duas foi possível verificar a associação de artefactos líticos a um depósito constituído por sedimento arenoso fino de origem fluvial e por material mais grosseiro, essencialmente granítico, proveniente da vertente localizada a sul da área intervencionada. Tais condições de jazida sugerem que as ocupações humanas da área terão ocorrido numa zona arenosa, ribeirinha, sujeita quer à dinâmica fluvial, quer a processos de erosão na vertente (Figura 6). O baixo, ou quase nulo, grau de rolamento dos artefactos líticos indicia algum transporte, todavia de curta distância. Alternativamente, este ligeiro rolamento das peças poderá decorrer do facto de elas se encontrarem num meio arenoso que seria periodicamente remexido pelas águas do Minho, criando-se assim condições favoráveis à sua abrasão.

A presença de bifaces entre os artefactos recolhidos na jazida de Bela permite relacioná-los com o tecno-complexo Acheulense. Ao contrário do que sucede nos loci 2 e 3 das Carvalhas, Melgaço (vide infra) e em alguns sítios da Galiza, nomeadamente Porto Maior (na margem direita do Minho, praticamente em frente à jazida de Bela) (Méndez-Quintas, 2017; Méndez-Quintas $\&$ alii, 2018), estes bifaces apresentam dimensões bastante reduzidas, aproximando-se assim dos exumados no locus 1 das Carvalhas (vide infra). Tendo sido alvo apenas de uma intervenção pontual, a jazida de Bela carece ainda de mais investigação, que será levada a cabo assim que possível.

\subsection{Concelho de Melgaço: os sítios das Carvalhas e Monte Crasto}

\section{Carvalhas}

No concelho de Melgaço, os trabalhos até agora realizados no âmbito do projeto Miño/Minho concentraram-se essencialmente na Veiga de Remoães, mais precisamente na denominada jazida de Carvalhas. Esta jazida foi por nós identificada em 2014, no decurso de prospeções arqueológicas levadas a cabo na área envolvente às Termas de Melgaço, onde Abel Viana, ainda na primeira metade do século $\mathrm{XX}$, havia assinalado a presença de materiais líticos talhados, que associou ao Paleolítico (Cunha-Ribeiro \& alii,, 2017). A identificação de materiais similares na superfície de alguns terrenos e em acumulações de seixos que servem para delimitar propriedades corroboraram as informações que nos foram dadas por colegas espanhóis que, em 2010, haviam visitado o local durante trabalhos de surriba numa das vinhas da área. Logo em 2014 confirmou-se a associação dos materiais líticos a terraços fluviais do rio Minho, o que motivou a realização dos trabalhos geoarqueólogicos subsequentes (Cunha-Ribeiro \& alii, 2017). 
A jazida das Carvalhas abrange uma área considerável, que inclui os loci 1, 2, 3 e 4. Nestes loci foi possível detetar distintos conjuntos artefactuais, de cronologia paleolítica, integrados em contextos sedimentares diversificados (Figura 7).

\section{Locus 1}

Apesar de extremamente antropizado - nomeadamente devido a trabalhos agrícolas e à abertura de uma vala, em tempos históricos, para drenagem de terrenos - o locus 1 conservou, nas depressões de um patamar granítico que ladeia um paleocanal do rio Minho (Figura 7), um depósito fluvial, que embala material lítico talhado com alguma abundância. Tendo em conta as suas características sedimentogenéticas, trata-se, muito provavelmente, de um depósito de inundação acumulado em ambientes de baixa energia (Figura 8), numa etapa em que o paleocanal estaria já colmatado e o rio Minho ainda acima do seu leito atual.

A coleção de artefactos líticos exumada no locus 1 inclui bifaces, que se caracterizam pelas suas reduzidas dimensões (Figura 8), e um número muito expressivo de produtos de debitagem, alguns dos quais retocados. As arestas vivas das peças e a sua concentração numa área relativamente restrita corrobora a hipótese de se estar perante uma coleção que sofreu pouco transporte.

\section{Loci 2 e 3}

Os loci 2 e 3 abrangem uma faixa que se estende, aproximadamente, desde o sopé do Monte Prado até ao patamar granítico onde se localiza o locus I (Figuras 7 e 9). Com recurso a meios mecânicos, abriu-se, no local, uma vala com cerca de $14 \mathrm{~m}$ de comprimento, que permitiu identificar um possante depósito fluvial ( $>4 \mathrm{~m}$ de espessura), que colmata um antigo canal (ou paleomeandro?) do rio Minho, cuja base se implanta a cerca de 10-15 $\mathrm{m}$ acima do leito atual. No extremo da vala, junto à base do Monte Prado, detetou-se uma interestratificação de sedimentos fluviais e sedimentos provenientes da vertente, que indicam a ocorrência de fluxos de detritos, de tipo debris flow, possivelmente controlados por fatores de ordem climática.

Muito embora o material lítico talhado ocorra tanto no depósito fluvial como nos depósitos de vertente, sugere-se, provisoriamente, que ele será proveniente de antigos depósitos existentes na base da encosta do Monte Prado, onde ainda hoje se conser- vam sob a forma de pequenas relíquias, tendo, no passado, deslizado em direção ao canal. De facto, as peças talhadas recolhidas em contexto de vertente não possuem boleamento das arestas. No entanto, esta característica física, ainda que pouco acentuada, observa-se no material que surge nos depósitos fluviais, tendo sido adquirida após a sua deposição no paleocanal do Minho.

Do ponto de vista cronológico-cultural, a indústria lítica dos loci 2 e 3 das Carvalhas é enquadrável no tecno-complexo Acheulense, sendo de destacar a presença de bifaces e de machados de mão de grande dimensão, produzidos a partir de seixos rolados de quartzito (Figura 9).

\section{Locus 4}

O locus 4, localizado junto à entrada da Quinta da Veiga (Figura 7), foi identificado em 2014, aquando de uma breve visita ao local. Nessa altura, por casualidade, detetou-se um biface semi-enterrado num caminho que conduz ao rio Minho, junto do qual se observou também um pequeno talude que cortava o rebordo de um terraço fluvial (Figura 10). Aquando do início dos trabalhos de campo nas Carvalhas, já no âmbito do projeto Miño/Minho (2016), identificaram-se nesse mesmo talude mais alguns artefactos líticos, nomeadamente um biface e um machado de mão. Em função destas descobertas, decidiu-se, em 2017, proceder à abertura de uma sondagem na superfície do terraço (Figura 10). Não obstante as reduzidas dimensões da sondagem $\left(4 \mathrm{~m}^{2}\right)$ e toda uma série de outros contratempos que impediram a sua escavação integral, foi possível recolher um pequena coleção de objetos líticos, enquadráveis no tecno-complexo Acheulense. Tais objetos, com vestígios de rolamento muito ténues e alguma eolização, surgem exclusivamente nos níveis arenosos da parte superior do terraço fluvial. Trabalhos arqueológicos posteriores permitiram reconhecer o revolvimento do setor sul do terraço, resultante da exploração mineira outrora aí desenvolvida. Os vestígios desta última atividade, testemunhados pela presença de pequenas conheiras, não eliminam, porém, o potencial arqueológico do locus 4 junto do talude inicialmente intervencionado, onde se tentará ainda desenvolver uma pequena escavação em área, que permita não só aumentar o número de artefactos líticos, como também melhor compreender os processos de formação do contexto geoarqueológico aí preservado. 


\section{Monte Crasto}

No concelho de Melgaço assinala-se ainda a existência de uma outra jazida acheulense, localizada na vertente meridional do Monte Crasto, na freguesia de Penso, a uma altitude absoluta próxima dos 230 $\mathrm{m}$. Os respetivos materiais líticos talhados foram ali recolhidos por um particular aquando de trabalhos de revolvimento do subsolo para a criação de uma pequena área de lazer.

No sentido de se detetar o depósito arqueológico, abriram-se com meios mecânicos diversas valas em vários pontos estratégicos, não se conseguindo, todavia, identificar qualquer formação antiga com a qual os materiais líticos se pudessem relacionar (Figura 11). De facto, nas referidas valas, que atingiram sempre o substrato granítico, observaram-se unicamente depósitos arenosos, de textura grosseira, nos quais se desenvolve um solo orgânico, de cor negra, muito pouco evoluído, com cerca de $1 \mathrm{~m}$ de espessura. Na periferia da área, os depósitos revelam claras perturbações de origem antrópica, havendo mesmo pontos com aterros recentes.

As peças líticas do Monte Crasto incluem produtos configurados e diversos produtos de talhe em proporções relativamente equilibradas, mesmo não descartando a possibilidade de na sua recolha ter existido alguma seleção dos objetos mais expressivos. O conjunto revela ainda uma manifesta homogeneidade, tanto pelas matérias-primas utilizadas, como pelas arestas muito boleadas de todas as peças. Tal facto não deixa de ser curioso dada a inexistência de qualquer linha de água nas imediações do sítio arqueológico. Perante esta situação, importa continuar a desenvolver trabalhos no local no sentido de se poder vir a determinar as reais condições de jazida destes artefactos líticos talhados, associáveis à presença do homem paleolítico numa posição topográfica do vale até agora desconhecida na área do projeto Miño/Minho.

\section{DATAÇÕES ABSOLUTAS NO ÂMBITO DO PROJETO MIÑO/MINHO}

No decurso das intervenções em Monção e em Melgaço recolheram-se, nas várias jazidas arqueológicas (Pedreira 2, Bela e Carvalhas), diversas amostras de sedimentos com o objetivo de realizar datações por OSL. Tais amostras foram extraídas por Lee Arnold e Martina Demuro, da Universidade de Adelaide, Austrália, tendo sido eles os responsáveis pelo seu processamento laboratorial no âmbito de um projeto de datações para jazidas pleistocénicas ibéricas. Os resultados entretanto obtidos (a publicar) corroboram a idade pleistocénica dos depósitos que embalam o material lítico talhado, não se afastando das datas conhecidas noutras áreas da região (Demuro et alii, 2020; Méndez-Quintas 2017, Méndez-Quintas \& alii, 2020a).

\section{CONCLUSÕES}

Num balanço preliminar dos trabalhos realizados entre 2016 e 2019 no âmbito do projeto Miño/Minho, pode afirmar-se que os dados coligidos testemunham a inegável importância arqueológica da margem esquerda do Baixo Minho para o estudo do Paleolítico peninsular, justificando plenamente o objetivo originalmente delineado de se vir a desenvolver tal estudo associando de forma integrada ambas as margens do rio.

Mesmo se os resultados obtidos têm levado a uma reprogramação dos trabalhos, concentrando-se esforços nas intervenções desenvolvidas nalgumas jazidas localizadas numa pequena área repartida entre os concelhos de Melgaço e de Monção, o número de jazidas já identificadas e as problemáticas a elas associadas permitem reformular de forma inovadora o nosso conhecimento sobre o Paleolítico da região, sendo também certo que o estudo das coleções de materiais líticos talhados entretanto recolhidos, e que se encontra já a ser desenvolvido, não deixará de reforçar tal situação.

Os materiais reunidos encontram-se associados tanto a contextos fluviais (de fundo de canal e níveis de inundação), como a depósitos coluvionares, revelando a presença do homem paleolítico em distintas posições na topografia do vale. Por outro lado, as indústrias líticas, genericamente associáveis ao tecno-complexo Acheulense, permitem vislumbrar a presença de alguns produtos configurados de grandes dimensões, elaborados quer a partir de grandes lascas, quer a partir de grandes seixos rolados, a par de outros conjuntos com materiais configurados de menor volumetria, nos quais os produtos de debitagem apresentam uma maior representatividade.

Urge, portanto, dar continuidade a este projeto, quer num quadro forçosamente interdisciplinar, quer numa necessária colaboração transfronteiriça, visando uma melhor caracterização das indústrias líticas localmente representadas, apurando o seu enqua- 
dramento cronológico e procurando a modelização da evolução da paisagem do vale, com o estudo da história da formação da bacia hidrográfica do rio Minho, desde as suas etapas mais antigas atéà formação da rede hidrográfica atual.

\section{BIBLIOGRAFIA}

AGUIRRE, Emiliano (1964) - Las Gándaras de Budiño, Porriño (Pontevedra). (Excavaciones Arqueologicas en España 31), Madrid: Ministerio de Educacion Nacional, Direccion General de Bellas Artes, Servicio Nacional de Excavaciones Arqueologicas.

BUTZER, Karl W. (1967) - Geomorphology and Stratigraphy of the Paleolithic Site of Budiño (Prov. Pontevedra, Spain). Eiszeitalter und Gegenwart, Band 18, Ohringen/ Württ, pp. 82-103.

CUNHA-RIBEIRO, João Pedro; MONTEIRO-RODRIGUES Sérgio; GOMES, Alberto; MÉNDEZ-QUINTAS, Eduardo; MEIRELES, José; PÉREZ-GONZÁLEZ, Alfredo; SANTONJA, Manuel (2017) - Ocupações Pleistocénicas na margem esquerda do Baixo Minho (Miño/Minho 2). Objetivos e primeiros resultados de um projeto transfronteiriço. In ARNAUD, J. M.; MARTINS, A., eds. - Arqueologia em Portugal/2017 - Estado da Questão. Lisboa: Associação dos Arqueólogos Portugueses, pp. 303-318.

CUNHA-RIBEIRO, João Pedro; MONTEIRO-RODRIGUES Sérgio; MÉNDEZ-QUINTAS, Eduardo; GOMES, Alberto; MEIRELES, José; PÉREZ-GONZÁLEZ, Alfredo; SANTONJA, Manuel (2017) - O Paleolítico de Melgaço. Vestígios dos primeiros habitantes do Concelho. Boletim Cultural de Melgaço, 10, pp. 117-15o.

DEMURO, Martina; ARNOLD, Lee. J.; DUVAL, Mathieu; MÉNDEZ-Quintas,Eduardo;SANTONJA,Manuel;PÉREZ-GONZÁLEZ, Alfredo (2020) - Refining the chronology of Acheulean deposits at Porto Maior in the River Miño basin (Galicia, Spain) using a comparative luminescence and ESR dating approach. Quaternary International (2020).

FERREIRA, Carlos; CUNHA-RIBEIRO, João Pedro; MONTEIRO-RODRIGUES, Sérgio; MÉNDEZ-QUINTAS, Eduardo; XAVIER, Pedro; MEIRELES, José; GOMES, Alberto; SANTONJA, Manuel; PÉREZ-GONZÁLEZ, Alfredo (2020) - A ocupação paleolítica da margem esquerda do Baixo Minho: a indústria lítica do sítio de Pedreiras 2 (Monção, Portugal) e a sua integração no contexto regional. (Neste volume).

GILES PACHECO, F.; CANO PAN, J. S.; SANTIAGO PÉREZ, A.; GUTIÉRREZ LÓPEZ, J. M.; MATA ALMONTE, E.; GRACIA PRIETO, J.; AGUILERA RODRÍGUEZ, L.; PRIETO REINA, O. (200o) - Poblamiento paleolítico en la cuenca media-baja del rio Miño. Sector la Guardia-Tuy (Pontevedra) - Cortegada (Orense). Secuencia cronoestratigráfica. In Actas do $3^{\circ}$ Congresso de Arqueologia Peninsular, Vol. II, Porto: ADECAP, pp. 101-121.
MÉNDEZ-QUINTAS, E. (2017) - Caracterización y variabilidad tecnomorfológica de las industrias achelenses de la Cuenca Baja del Río Miño (NO de la Península Ibérica). Tesis Doctoral, Universidad de Burgos, Escuela Interuniversitaria de Posgrado en Evolucion Humana, CENIEH, Universidad de Alcalá, Universidad de Oviedo, p. 628.

MÉNDEZ-QUINTAS, E.; SANTONJA, M.; PÉREZ-GONZÁlEZ, A.; ARNOLD, L. J.; CUNHA-RIBEIRO, J. P.; DEMURO, M.; DÍAZ-RODRÍGUEZ, M.; DUVAL M.; GOMES, A.; MEIRELES, J.; MONTEIRO-RODRIGUES, S.; SERODIO DOMÍNGUEZ, A. (2018a) - El Yacimiento Achelense de As Gándaras de Budiño: Síntesis y perspectivas después de 50 años de desencuentros. Estudos do Quaternário/ Quaternary Studies, 19, pp. 1-22. DOI: https:// doi.org/10.30893/eq.voi19.182

MÉNDEZ-QUINTAS, E.; SANTONJA, M.; PÉREZ-GONZÁlEZ, A.; DUVAL, M.; DEMURO, M.; ARNOLD, L. J. (2018b) - First evidence of an extensive Acheulean large cutting tool accumulation in Europe from Porto Maior (Galicia, Spain). Scientific Report 8:3082 doi: 10.1038/ S41598-018-21320-1

MÉNDEZ-QUINTAS, E.; SANTONJA, M.; PÉREZ-GONZÁlEZ, A.; DEMURO, M.; ARNOLD, L. J.; DUVAL, M. (2019a) - Límites cronológicos de la presencia humana durante el Pleistoceno medio en la cuenca baja del Río Miño (Pontevedra, España). In XV Reunión Nacional de Cuaternario (Bilbao 2019), AEQUA, pp. 51-54.

MÉNDEZ-QUINTAS, E.; DEMURO, M.; ARNOLD, L. J.; DUVAL, M.; PÉREZ-GONZÁlEZ, A.; SANTONJA, M. (2019c) - Insights into the late stages of the Acheulean technocomplex of Western Iberia from the Arbo site (Galicia, Spain). Journal of Archaeological Science: Reports, 27, p. 101934 .

MÉNDEZ-QUINTAS, Eduardo; SANTONJA, Manuel; PÉREZ-GONZÁLEZ, Alfredo, ARNOLD, Lee J.; DEMURO, Martina; DUVAL, Mathieu (2020a) - A multidisciplinary overview of the lower Miño River terrace system (NW Iberian Peninsula). Quaternary International (2020).

MÉNDEZ-QUINTAS, E.; SANTONJA, M.; ARNOLD, L. J.;CUNHA-RIBEIRO, J. P.; SILVA, P. X. da; DEMURO, M.; DUVAL, M.; GOMES, A.; MEIRELES, J.; MONTEIRO-RODRIGUES, S.; PÉREZ-GONZÁLEZ, A. (2020b) - The Acheulean Technocomplex of the Iberian Atlantic Margin as an example of technology continuity through the Middle Pleistocene. Journal of Paleolithic Archaeology. https://doi. org/10.1007/s41982-020-00057-2

TEXIER, Jean-Pierre (1984) - Le site paléolithique de Budiño. Portugália, IV-V, pp.34-35.

TEXIER, J.-P.; VIDAL ENCINAS, J. (1981) - Nuevas excavaciones arqueológicas en las Gándaras de Budiño. Primeros resultados. La estratigrafía. In DÁZ DEL OLMO, F.; MARQUEZ FERNÁNDEZ, D.; RUBIO RECIO, J. M., eds. - Actas de la VReunión del Grupo Español de Trabajo del Cuaternario, pp. 210-220. 
VIDAL ENCINAS, J. M. (1982a) - Las Gándaras de Budiño: balance preliminar de dos campañas de excavaciones (19801981). Pontevedra: Museo de Pontevedra, Tomo XXXVI, pp. 91-113.

VIDAL ENCINAS, J. M. (1982b) - O Paleolitico Inferior no Baixo Miño, Marxe galega: unha aproximación. Brigantium, Vol. 3, pp. 7-32.

VIVEEN, Willem (2013) - Multi-scale Tectonic Controls on Fluvial Terrace Formation in a Glacioeustatically-dominated River System. Inferences from the Lower Miño Terrace Record. Wageningen University, The Netherlands (Phd thesis, 222 p.).

VIVEEN, W.; BRAUCHER, R.; BOURLÈS, D.; SCHOORL, J. M.; VELDKAMP, A.; van BALEN , R. T.; WALLINGA, J.; FERNANDEZ-MOSQUERA, D.; VIDAL-ROMANI, J. R.; SANJURJO-SANCHEZ, J. (2012) - A o.65 Ma chronology and incision rate assessment of the NW Iberian Miño River terraces. Global and Planetary Change, 94-95, pp. 82-10o.
VIVEEN, W.; SCHOORL, J. M.; VELDKAMP, A.; van BALEN, R. T.; VIDAL-ROMANI, J. R. (2013a) - Fluvial terraces of the northwest Iberian lower Miño River. Journal of Maps, Vol. 9, 4, pp. 1-10.

VIVEEN, W.; SCHOORL, J. M.; VELDKAMP, A.; van BALEN, R. T.; DESPRAT, S.; VIDAL-ROMANI, J. R. (2013b) - Reconstructing the interacting effects of base level, climate, and tectonic uplift in the lower Miño River terrace record. A gradient modelling evaluation. Geomorphology, 186, pp. 96-118.

VIVEEN, W.; SCHOORL, J. M.; VELDKAMP, A.; van BALEN, R. T. (2014) - Modelling the impact of regional uplift and local tectonics on fluvial preservation. Geomorphology, 210, pp. 119-135.

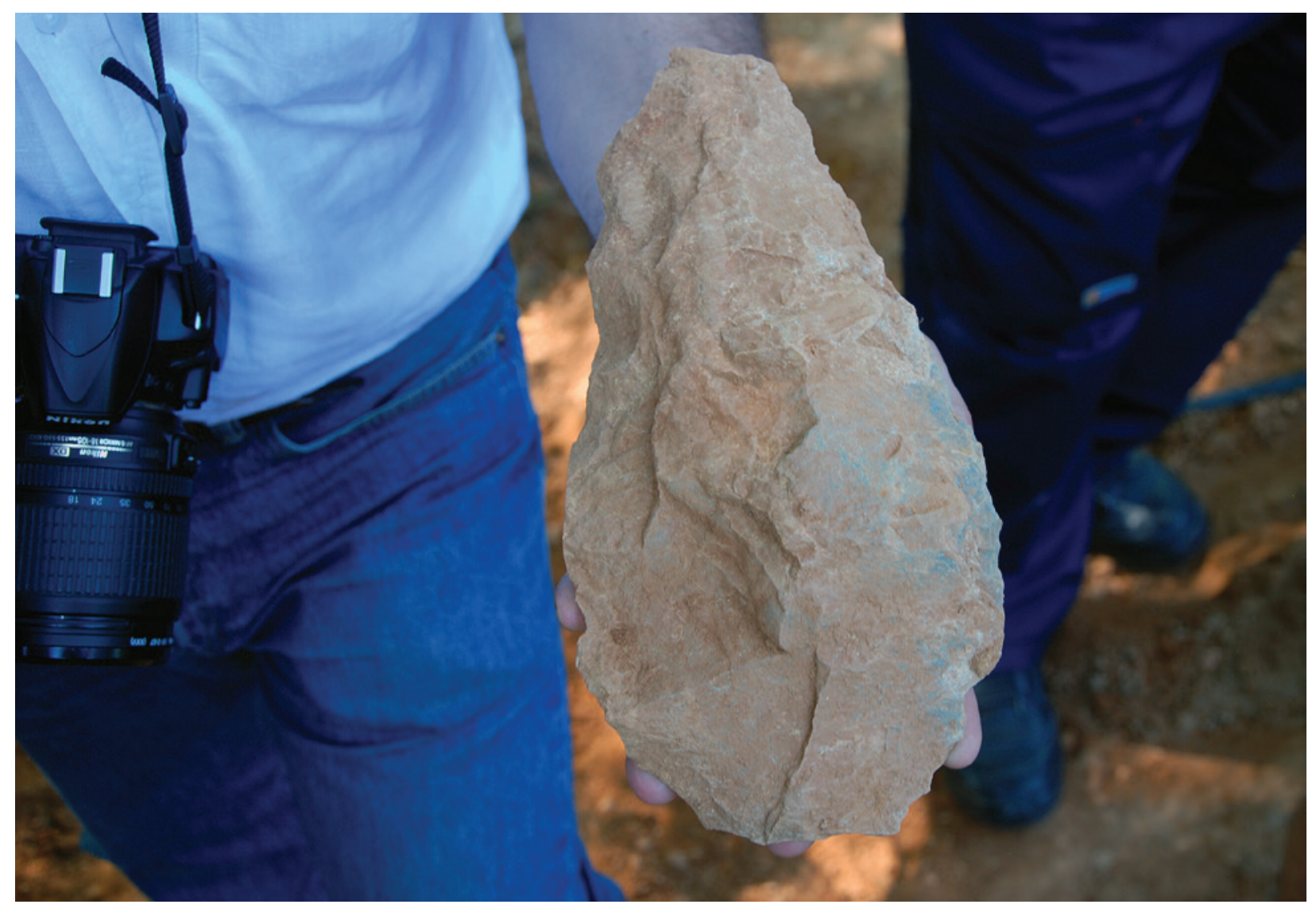

Figura 1 - Biface de grandes dimensões da jazida de Porto Maior, As Neves (Galiza). 


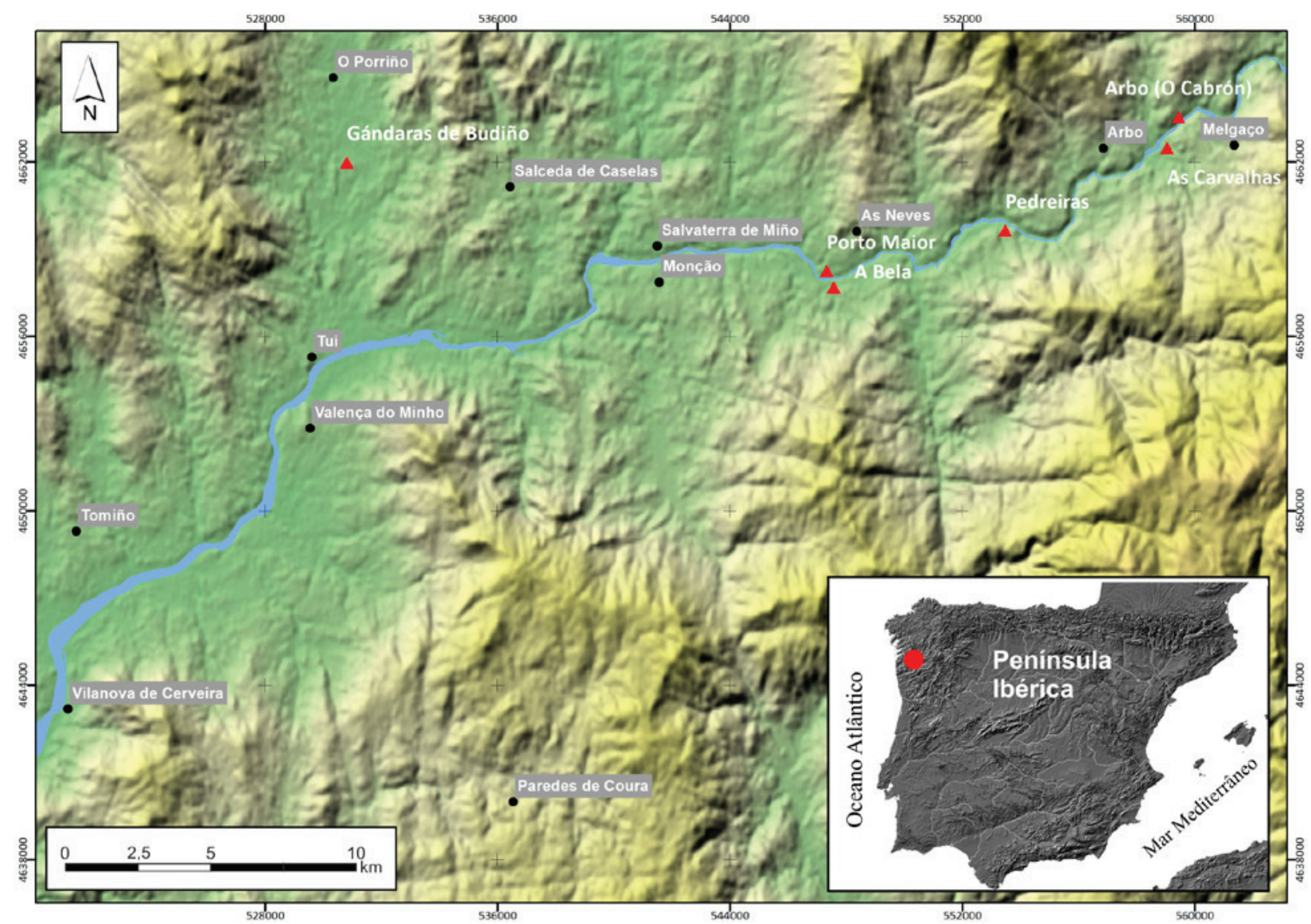

Figura 2 - Delimitação aproximada da área abrangida pelo Projeto Miño/Minho. Triângulos: principais jazidas paleolíticas intervencionadas, quer no âmbito do projeto Miño/Minho, quer no âmbito de outros projetos desenvolvidos na Galiza.

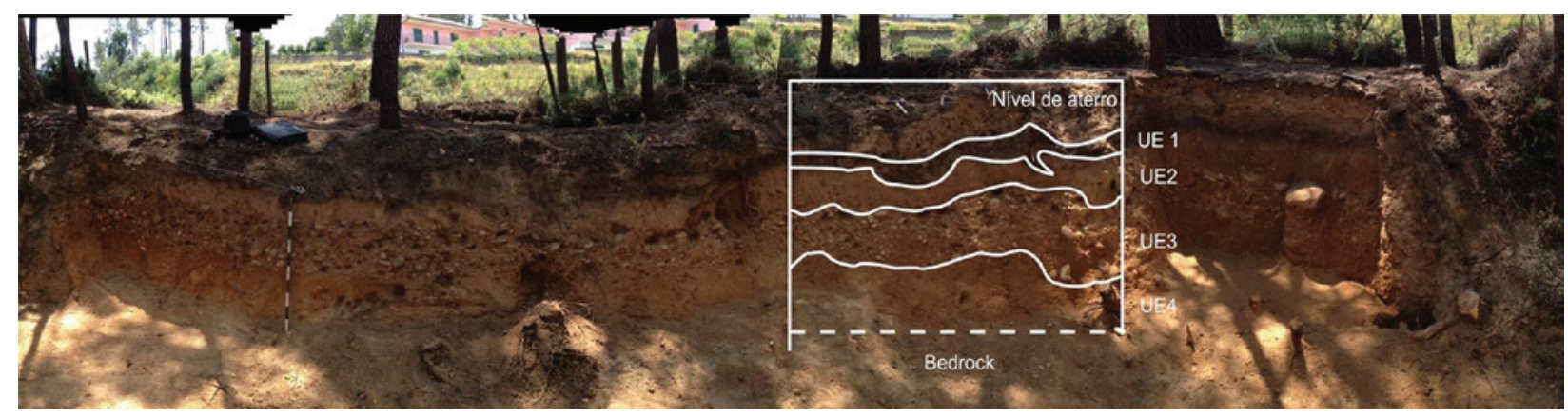

Figura 3 - Jazida de Predreiras 1, Monção. Corte regularizado durante os trabalhos de campo de 2016. Descrição estratigráfica sumária: UE1 - Solo orgânico recente enterrado por um nível de aterro; UE2 - Depósito silto-arenoso, maciço, de cor alaranjada, possivelmente de origem eólica, com um número muito reduzido de artefactos líticos talhados; UE3 - Depósito rico em seixos rolados de quartzito e quartzo e com clastos angulosos de granito, matriz-suportados, sem qualquer estruturação sedimentar, no qual se encontrou a maior parte da indústria lítica talhada; UE4 - Alterite granítica parcialmente remobilizada e com evidências de bioturbação. 


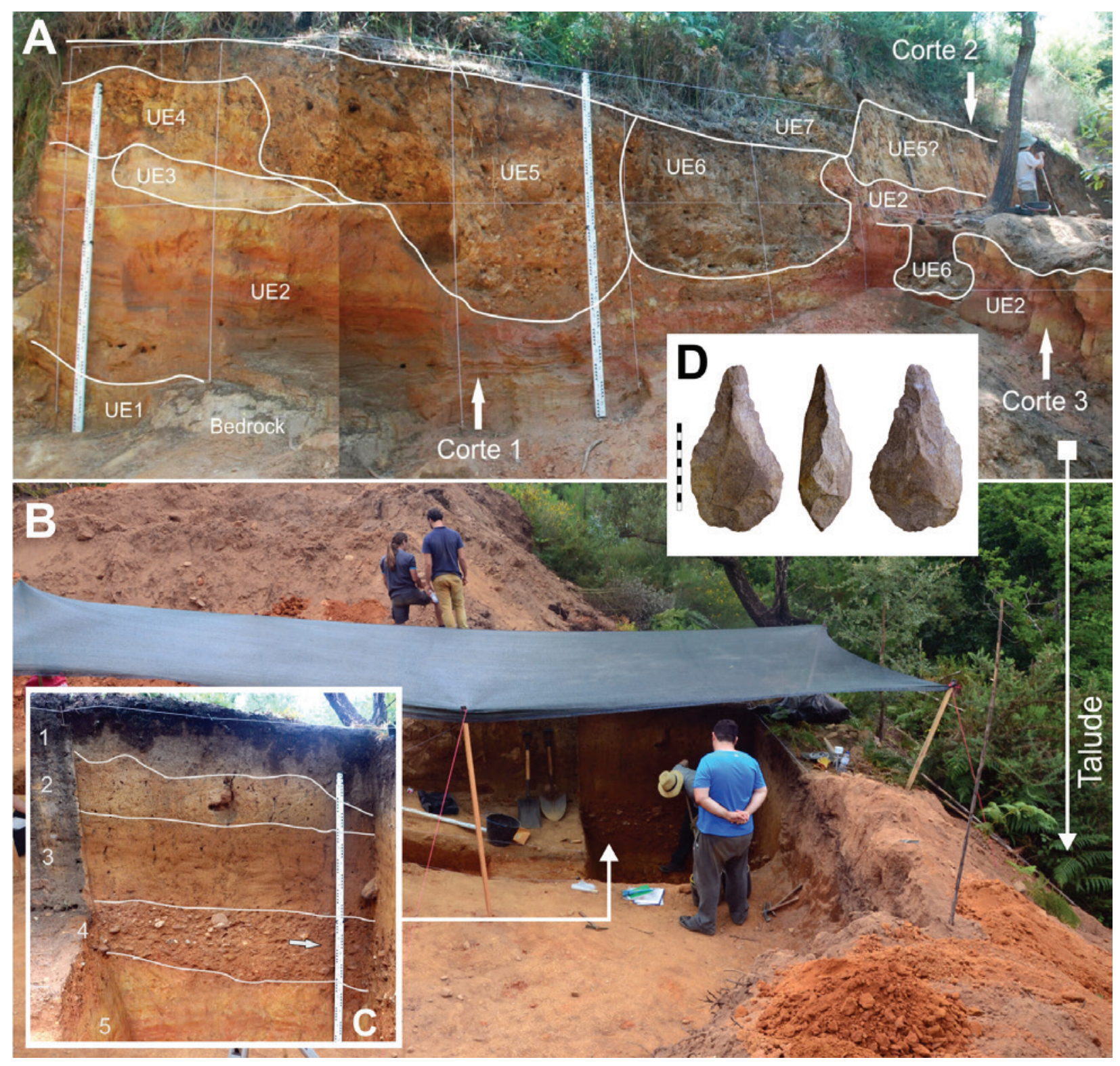

Figura 4 - Jazida de Pedreiras 2, Monção. A - Talude onde se identificou o biface (foto D) que conduziu à descoberta da estação arqueológica. Descrição estratigráfica sumária: UE1, UE2, UE3 - Depósitos fluviais arenosos com estratificação horizontal, arqueologicamente estéreis (cota da base: $35 \mathrm{~m}$ acima do leito atual do rio Minho); UE4, UE5, UE6 - Depósitos coluvionares em canais que se entrecortam; UE7 - Solo atual. B - Plataforma sobre o talude, intervencionada em 2016 (sondagem 1) e 2017. C - Sequência estratigráfica observada na área da sondagem 1: UE1 - Solo atual; UE2 e UE3 - Depósito silto-arenoso, possivelmente eólico; UE4 - Depósito coluvionar onde surge o material lítico talhado; UE5-Depósito fluvial arenoso, correspondente à UE2 do talude. 


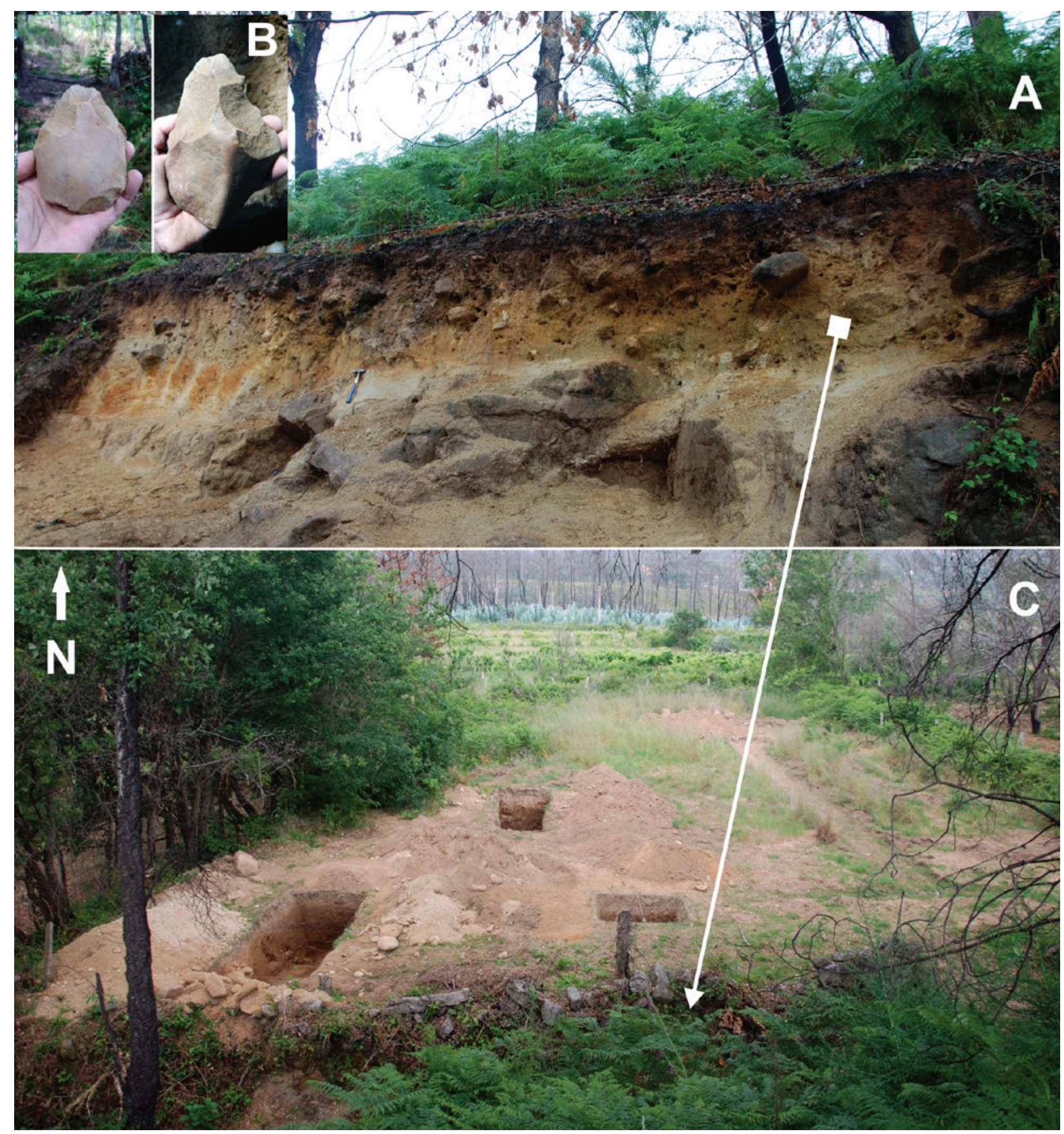

Figura 5 - Sítio de Bela, Monção. A - Talude subjacente à EN 202, limpo em 2018; B - Bifaces recolhidos no local durante a limpeza do talude; C - Implantação das sondagens sobre o terraço fluvial, em 2019. 

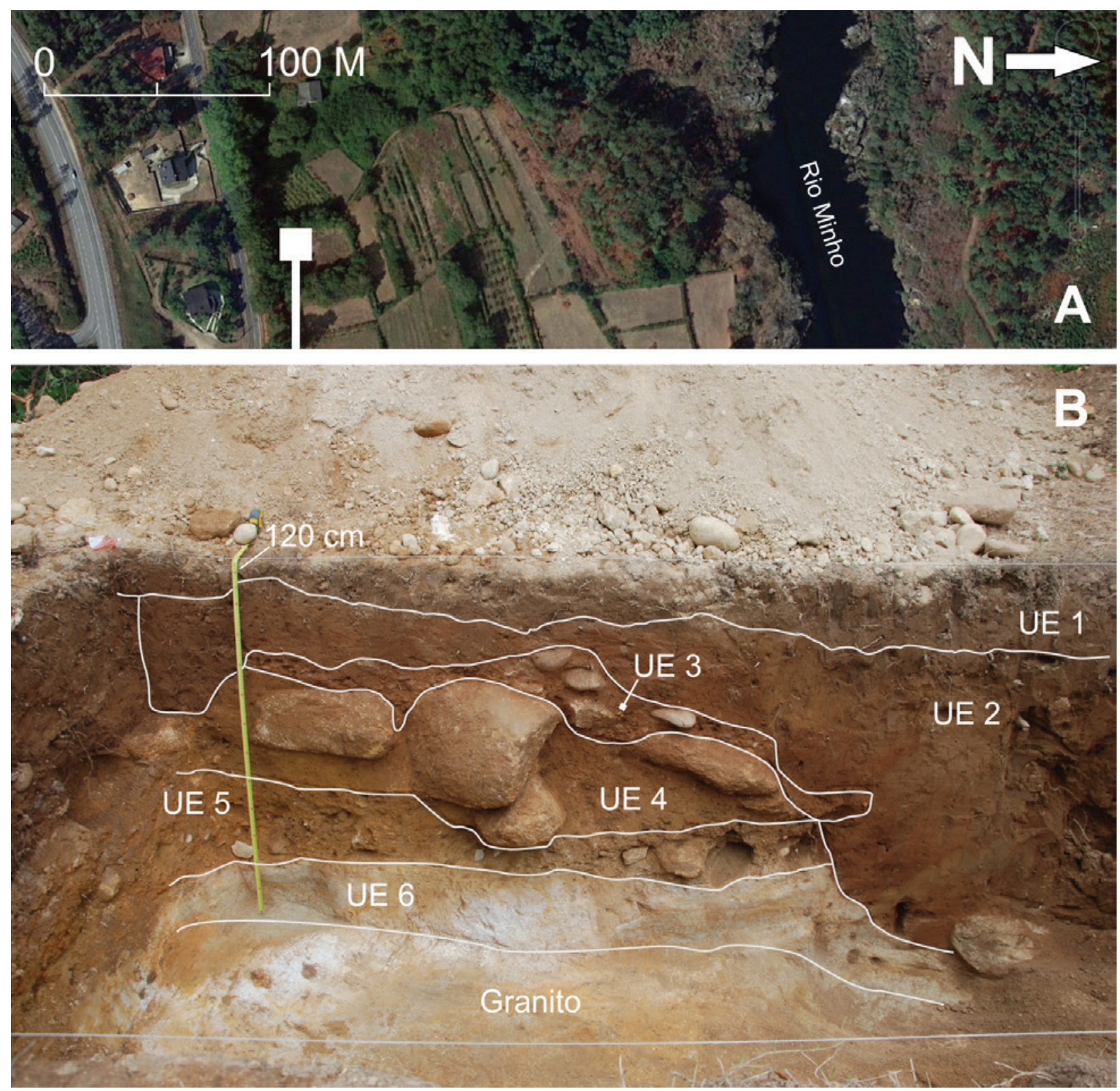

Figura 6 - Sítio de Bela, Monção. A - O quadrado branco assinala o talude da EN 202 limpo em 2018 e a área intervencionada em 2019. B - Estratigrafia observada numa das sondagens. Descrição sumária: UEı - Solo atual (afetado pelos trabalhos agrícolas); UE2 - Depósito silto-arenoso aluvionar; UE3 - Depósito coluvionar; UE4 - Depósito coluvionar claramente relacionado com o desmantelamento da vertente localizada a sul; UE5 - Depósito areno-siltoso constituído por areias fluviais e material de vertente, que embala artefactos líticos talhado: UE6 - Areias finas fluviais, na base das quais aparecem pontualmente seixos rolados de quartzito. Este material, que assenta no substrato granítico, faz parte da cobertura sedimentar do terraço do Minho implantado a cerca de $25 \mathrm{~m}$ acima do curso atual. 

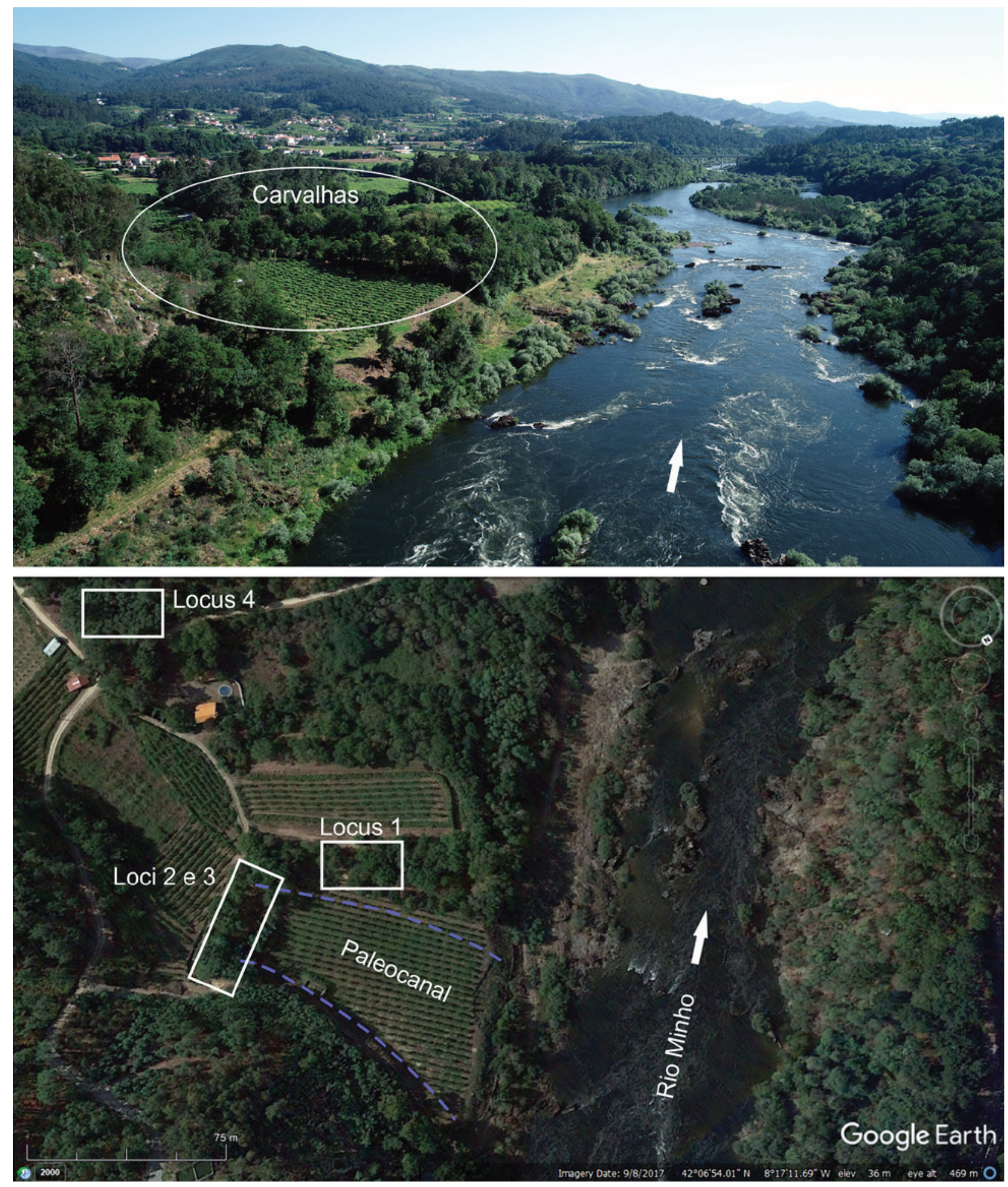

Figura 7 - Vista aérea para SW da jazida das Carvalhas, Melgaço, indicando-se os diversos loci intervencionados e um paleocanal do rio Minho. 


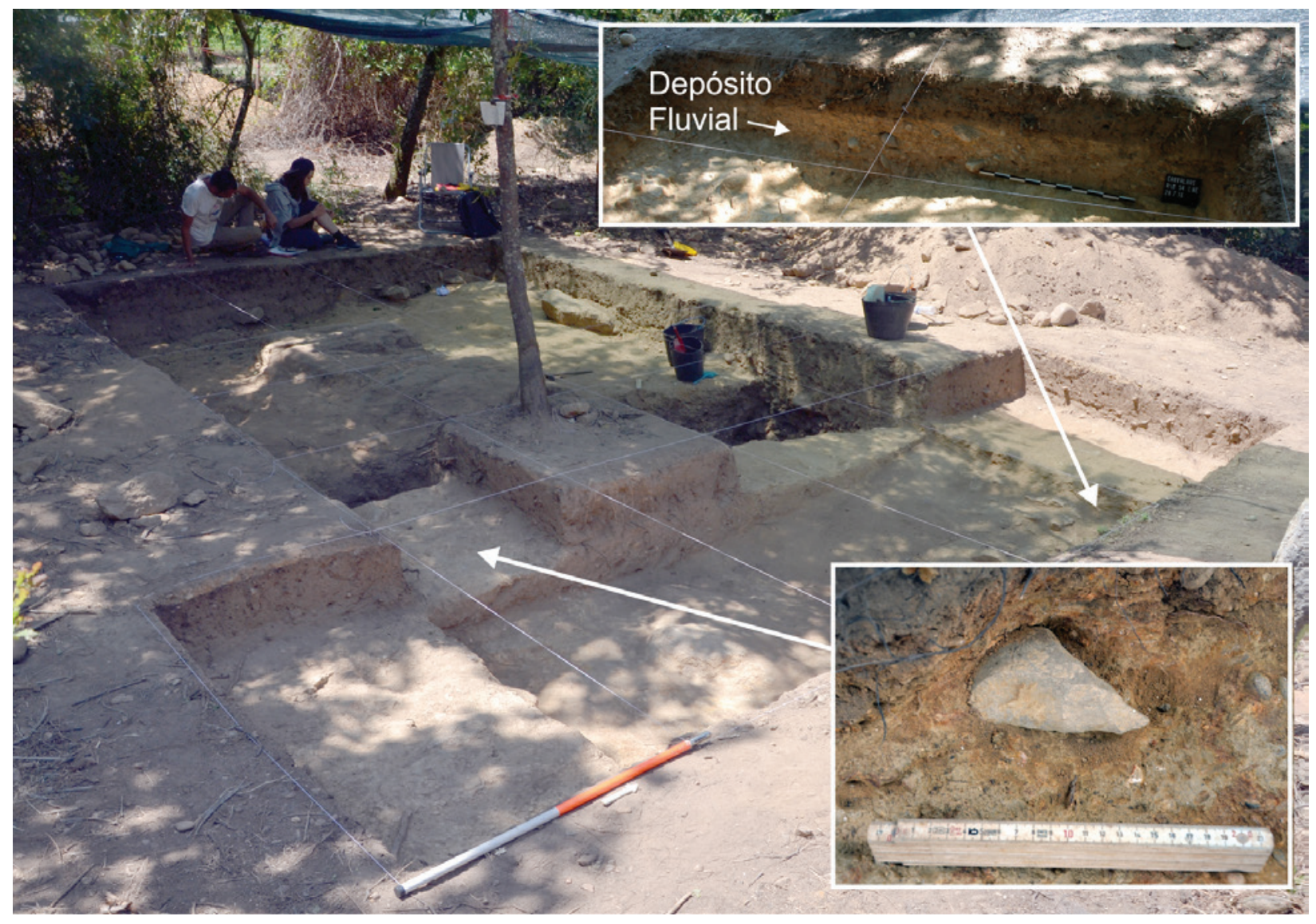

Figura 8 - Locus 1 durante a campanha de escavação de 2017. O material lítico associa-se a um depósito de origem fluvial, que se conserva apenas nas depressões do bedrock granítico. Trata-se de um depósito com matriz arenosa fina, de cor alaranjada, muito concrecionado, que embala pequenos seixos rolados de quartzito, bem imbricados. A superfície granítica que lhe subjaz, implantada a cerca de $20 \mathrm{~m}$ acima do curso atual do Minho, apresenta vestígios de erosão fluvial, nomeadamente polimento. 


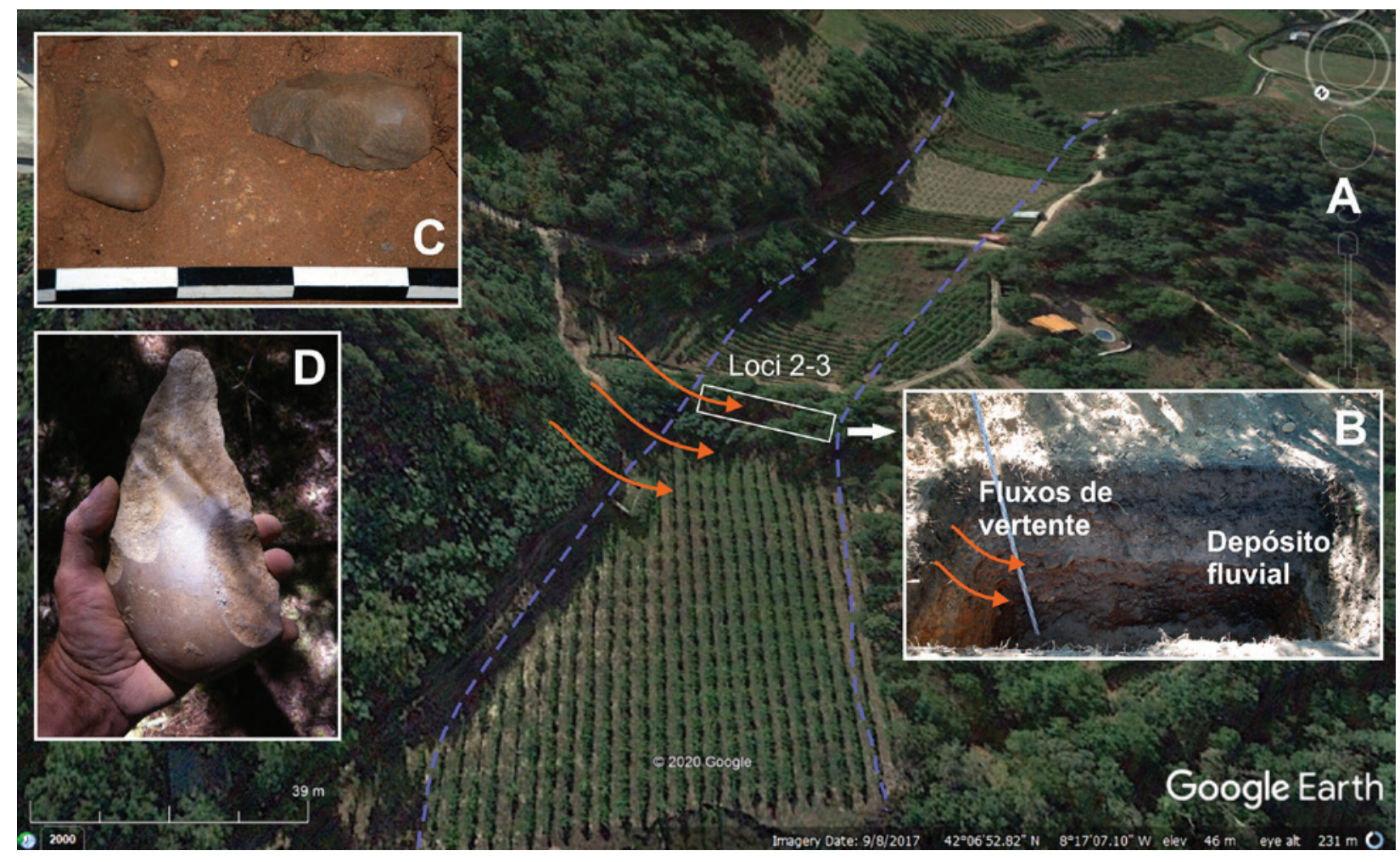

Figura 9 - Localização dos loci 2 e 3 da jazida das Carvalhas. A - Posição dos loci no paleocanal do rio Minho, assinalando-se os fluxos de vertente no sentido do canal, a partir do sopé do Monte do Prado. B - Interestratificação de sedimentos fluviais (conglomeráticos, clasto-suportados) e sedimentos de vertente (conglomeráticos, matriz-suportados, ricos em fragmentos angulosos de granito) numa sondagem aberta em 2016. C - Bifaces recolhidos no depósito fluvial, na zona de interestratificação. D - Biface de grandes dimensões recolhido no depósito fluvial. Observe-se o ténue boleamento das arestas. 


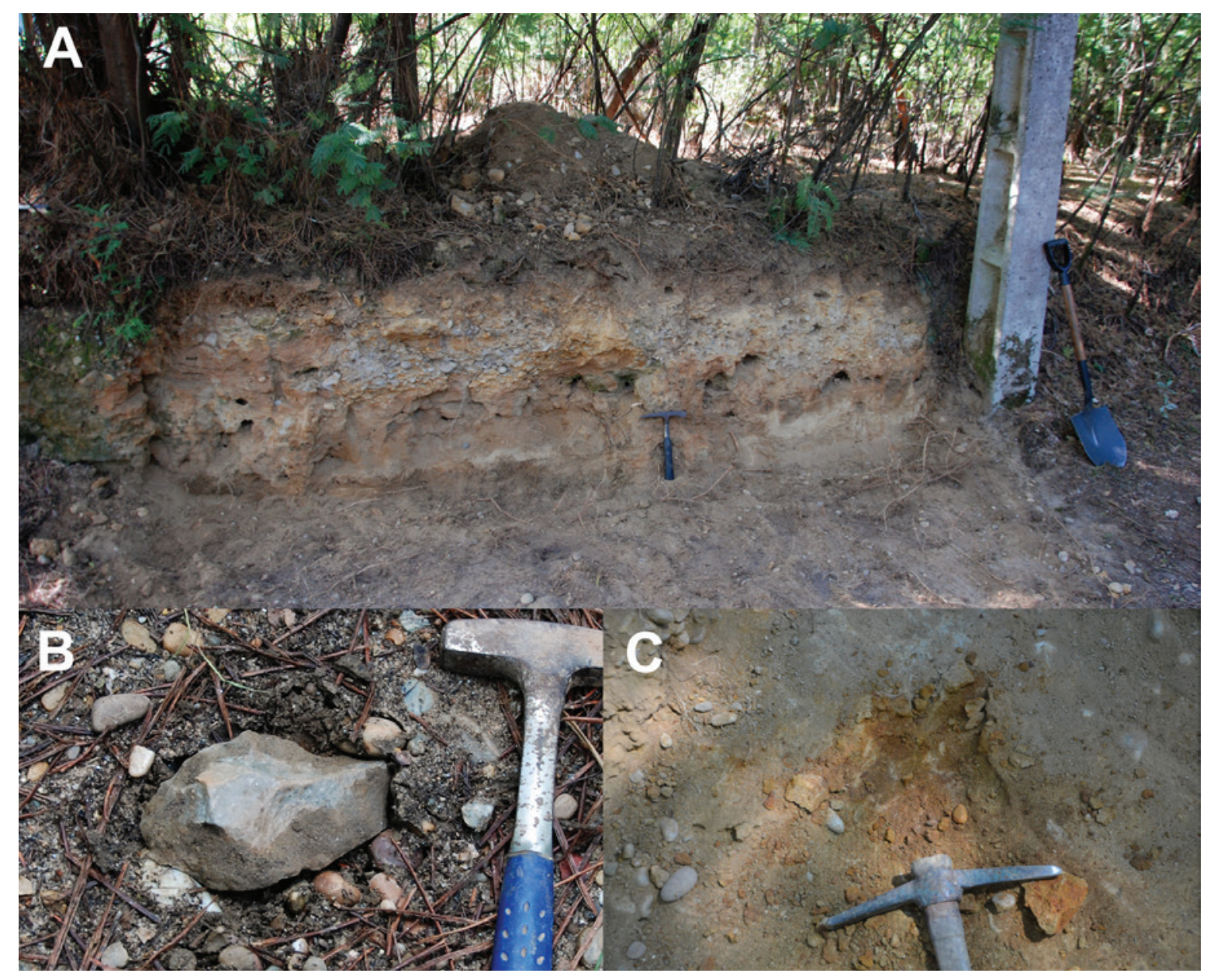

Figura 1o - Locus 4 das Carvalhas. A - Talude junto ao caminho que conduz ao rio Minho, onde se observam sedimentos que fazem parte de um terraço fluvial implantado à cota de $20 \mathrm{~m}$ acima do leito atual do rio. B - Biface encontrado em 2014, que permitiu a identificação do sítio arqueológico. C - Sedimento arenoso que embala o material lítico talhado (níveis superiores), observado na sondagem realizada em 2017.

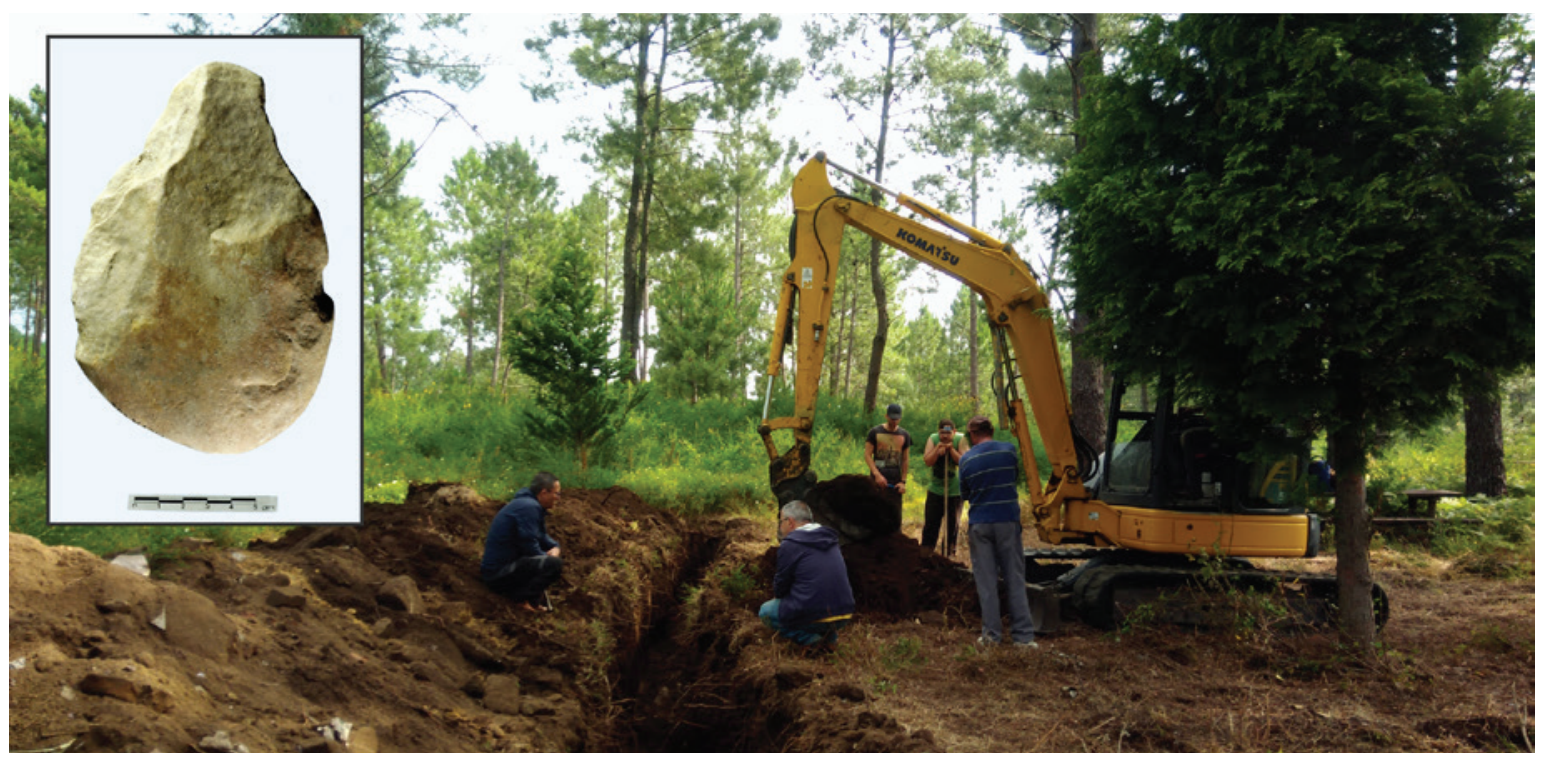

Figura 11 - Monte Crasto, Penso. Abertura de valas com recurso a meios mecânicos e exemplar de biface pertencente à coleção recolhida no local (pelo Sr. José Cardoso, de Penso). 



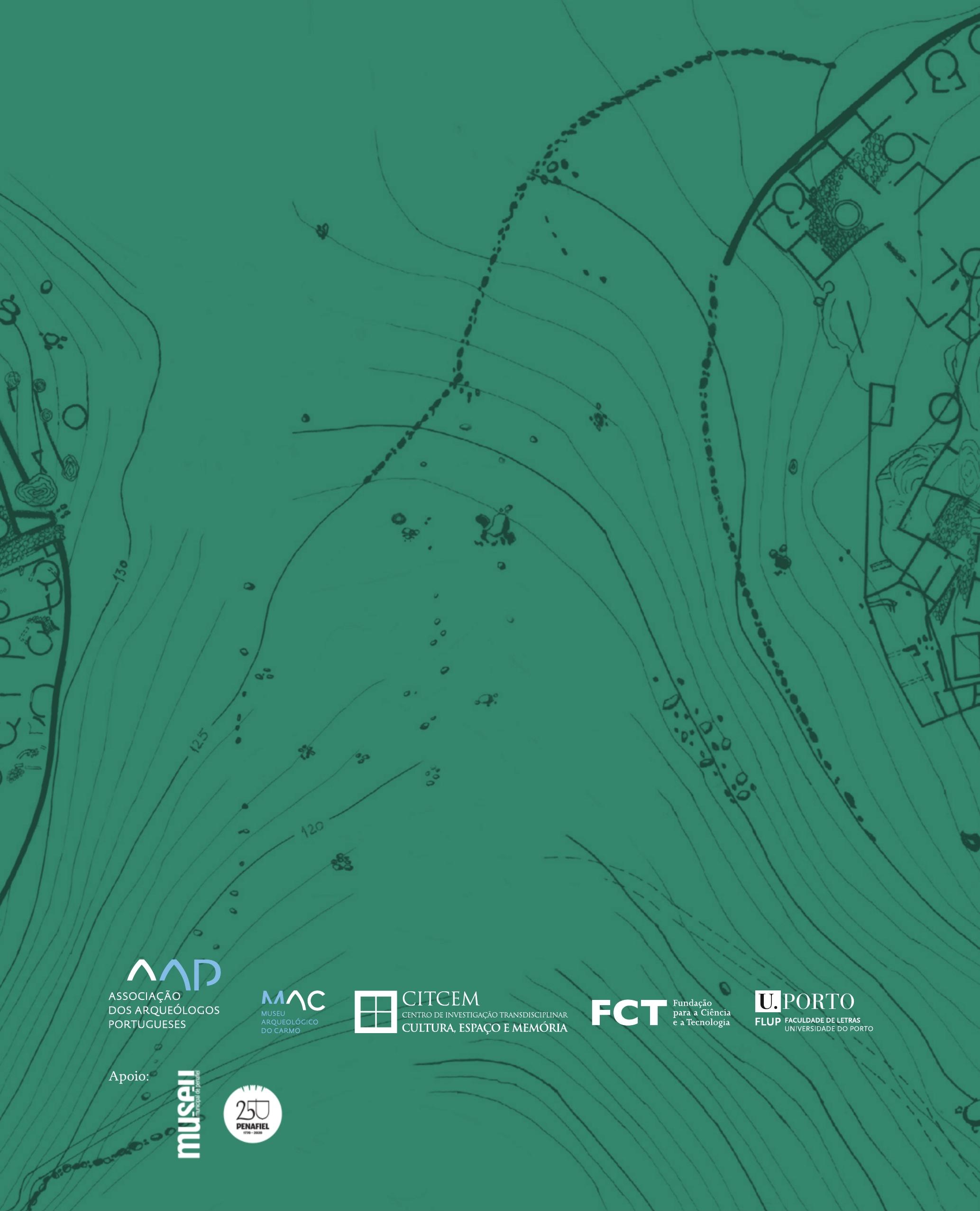

